\title{
Apeus välittyvänä, kuunneltuna ja koettuna
}

\author{
Affektiiviset kehät ja itkuvirsien tunteiden ilmeneminen arkistoäänitteillä
}

\section{Viliina Silvonen}

"[l]tku käypi niin karkialla, oikein karwoille käywällä, läpi ruumiin ja jäsenten wihlasewalla äänellä, että wielä wuodenki päästä sitä muistellessani olen kun säykähyksissä. - - mikä lie eräälle nuoremmalle naiselle päähän pistänyt, rupesi yhtäkkiä kaikesta kurkusta itkemään wirttänsä, että oikein kammotti kuullakseni - -" (Lönnrot 1836.)

Näin jyrkin sanakääntein Elias Lönnrot kuvasi kokemustaan itkuvirsien eli itkujen kuulemisesta syyskuussa 1836. Volmari Porkan noin viisikymmentä vuotta myöhemmästä kuvauksesta välittyy ymmärtävämpi suhtautuminen itkuvirsiesityksen tunnelataukseen: "Hän [itkijä] ei enää huomaa mitäkään ympärillään, suru on kokonaan vallannut hänet. Vaan eivätpä läsnä-olijatkaan kylmäkiskoisina kuuntele häntä; itkijän intohimoinen laulu on lumonnut heidätkin" $(1883,200)$. Molemmissa kuvauksissa tunne on konkreettisesti läsnä. Esittäjän tunnetilan syveneminen eli itkijän apeutuminen on tyypillistä ja tavoiteltavaa itkuvirttä esitettäessä eli äänellä itkettäessä. Myös tunnetilan välittyminen kuulijoille on olennaista. Folkloristiikassa itkuvirret käsitetään erotilanteiden rituaaleihin liittyvänä kansanperinteen lajina, joka heijastaa myyttisiä käsityksiä ja välittää kulttuurisia merkityksiä (esim. Honko 1963; Stepanova, E. 2014). Rituaalisena, myyttistä maailmankuvaa heijastavana perinteenä karjalaiset itkuvirret eivät enää elä, mutta itkuperinne on saanut uudenlaisia muotoja sosiaalisen ja kulttuurisen ympäristön muuttuessa (ks. esim. Tenhunen 2006; Wilce 2009a; 2011). Vaikka tunteet on tunnistettu keskeiseksi äänellä itkemisessä, ei aiempi tutkimus ole niihin paria poikkeusta lukuun ottamatta tarttunut (ks. Urban 1988; Tolbert 1988; 1990; Wilce 2009a). Tässä aineistolähtöisessä tutkimuksessa keskityn Aunuksen Karjalassa 1940-2001 tallennettuihin itkuvirsiäänitteisiin ja tunteiden moninaisuuteen näissä itkuvirsissä. Tutkimusintressini on folkloristinen: tähtään suullisen perinteen, kulttuurisen kommunikaation ja kulttuuristen merkitysten välittymisen ymmärtämiseen. Tulokseni syventää ymmärrystä itkuvirsiperinteestä ja monipuolistaa tapoja jäsentää itkuvirsiä, täydentää folkloristista arkistotutkimusta ääniteanalyysien osalta sekä tarjoaa uusia tapoja hahmottaa tunnetta ja tunteiden moninaisuutta arkistoaineistossa.

Lähestyn tunnetta tutkimuskohteena eri tasoilla: itkijän ilmaisuna ja kokemuksena, sekä tunteen ilmenemistä jäljitellen esitettynä ja koetusta kumpuavana. Tunteista vaikuttumisen, liikuttumisen ja tunteiden välittymisen ilmiöitä lähestyn affektiivisuuden käsitteellä, ja itkuvirsien ympärille muodostuvia erilaisia affektiivisia suhteita kutsun affektiivisiksi kehiksi. 
Itkuvirsien melankolisista tunteista ja itkijän näihin tunteisiin vajoamisesta käytän apeuden ja apeutumisen käsitteitä, jotka olivat myös itkijöiden itsensä käytössä (myös Stepanova, E. 2014, 99-100). "Apeus" sisältää moniulotteisesti melankolisia tunnevivahteita alakulosta ahdistukseen ja kärsimyksestä kaihoisuuteen. ${ }^{1}$

Analyysissani arkistoaineistosta hahmottuu apeuden ilmenemisen kannalta kolmenlaisia itkuvirsiesityksiä: affektiivisia, tunnetta jäljitteleviä ja esityksiä, joissa tunne ei ilmene. Tutkimukseni mukaan se, että kuuntelija havaitsee jollakin tasolla apeuden ilmenemisessä jäljitellyn ja koetusta kumpuavan välisen eron ja muutoksen jäljitellystä kokemuspohjaiseen, on itkijän apeutumisen tulkitsemisen ja esityksen affektiivisuuden kannalta olennaista. Tunteen ilmenemisen jaottelu jäljiteltyyn ja koetusta kumpuavaan yhdistää tutkimukseni autenttisuuskeskusteluihin, joita on käyty muun muassa esittävän taiteen tutkimuksessa länsimaiseen musiikkikulttuuriin ja sen autenttisuuden ihanteisiin liittyen (mm. Kemal ja Gaskell 1999, 1-11; Anttonen 2019). Tällaiset autenttisuuskysymykset eivät suoranaisesti vastaa itkijöiden omia jäsennyksiä, mutta tutkijana teen tätä analyyttista jaottelua ja tulkintoja modernin yhteiskunnan ja tutkimuksen keskustelujen piiristä etisistisestä näkökulmasta. Perinteisenä rituaalisen käytäntönä itkuvirret eivät suoraan vertaudu länsimaisiin musiikkikulttuureihin. Lisäksi tunteen ilmeneminen jäljitellen ja koetusta kumpuavana ovat molemmat itkuvirsille ominaisia, ja näiden erottelu on jossain määrin olemassa myös itkijöiden itsensä ymmärryksessä. Arkistoaineiston haastatteluiden perusteella ymmärrän apeutumisen tarkoittavan nimenomaan koetusta kumpuavaa tunnekokemusta. Itkijät eivät välttämättä ole erotelleet apeuden jäljittelyä ja apeutumista ainakaan autenttisuusnäkökulmasta, vaan apeuden jäljittely, apeutuminen ja näiden välimuodot ovat osa äänellä itkemisen käytäntöä. Ne ovat kulttuurisesti ja sosiaalisesti omaksuttua ja automatisoitunutta, konventionaalinen tapa toimia. Itkijää, joka ei äänellä itkiessään apeutunut tai saanut kuulijoita herkistymään, pidettiin huonona (esim. Kper AK/2940), ja toiset itkijät ovat arvostelleet tunteettomia itkuvirsiesityksiä halveksuen laulamiseksi (Stepanova, E. 2014, 98-99).

Itkuvirsien tunteiden monimuotoisuuden ja affektiivisuuden analysoiminen edellyttää kokonaisvaltaista itkuvirsiperinteen ymmärtämistä aina omaleimaisesta erikoisesta runokielestä tunteen ilmentämisen ja ilmenemisen genrekohtaisiin käytäntöihin sekä tradition kulttuurisiin merkityksiin. Karjalainen itkuvirsiperinne on minulle lähtökohtaisesti kulttuurisesti, ajallisesti ja paikallisesti vieras, mutta olen kerryttänyt riittävän kompetenssin kuunnellessani arkistoäänitteitä sekä perehtyessäni aiempaan tutkimukseen (esim. Honko 1963; Nenola-Kallio 1982; Konkka 1985; Tolbert 1988; Stepanova, E. 2014). Jotta pääsen selville siitä, miten ja miksi itkuvirsiäänite on affektiivinen sekä miten voin tulkita tunnetilan muutoksia kuuntelemisen perusteella, on ensin saatava selville, miten tunne ilmenee itkuvirsissä ja mitä tunneintensiteetin yltymisessä tapahtuu. Lisäksi on analysoitava, miten jäljitelty ja koetusta kumpuava tunteen ilmeneminen ovat suhteessa toisiinsa. Tämän jälkeen on vielä hahmotettava näiden itkuvirren eritasoisten tunteeseen liittyvien ilmiöiden suhteita toisiinsa.

Artikkelin tutkimusasetelma rakentuu kolmen aineistolähtöisen näkökulman ympärille. Ensimmäinen näkökulma on äänellä itkemisen ja itkuvirren tunteen tasot eli tunnekokemus, tunneilmaisu ja tunteen ilmeneminen. Analysoin, mitä kaikkea karjalaisten itkuvirsien tunteet ovat arkistoäänitteillä ja mitä ovat ne itkuvirren piirteet, jotka ilmentävät tunnetta. Toinen aineistosta nouseva kysymys liittyy arkistoäänitteellä kuuluvaan itkijän apeutumiseen, 
jota tarkastelen tunteen ilmenemisen ja tunneintensiteetin muutoksina. Tähän liittyy myös kolmas näkökulma, jossa tarkastelen itkuvirsien ja äänellä itkemisen moniulotteisena hahmottuvaa affektiivisuutta ja hahmottelen affektiivisia kehiä. Affektiivisuutta analysoin siis itkijän apeutumisen lisäksi itkijän apeutumisen välittymisenä kuuntelijoille. Kuuntelijoille välittymisessä keskityn siihen, miten apeutta ja itkijän apeutumista voi tunnistaa, ja tämän analysoinnissa hyödynnän välineenä myös omaa kuuntelukokemustani.

Lähestyn kysymyksiä tunne- ja affektiteorioiden näkökulmasta. Analyysissa erittelen arkistoäänitteellä kuuluvaa itkuvirttä ja tunnetta. Lisäksi selvitän pientä vertailuryhmää käyttäen, välittyykö itkuvirsien affektiivinen sisältö myös itkuvirsitraditiota tuntemattomille. Vertailuryhmä täydentää oman kuuntelukokemukseni analyysia ja osaltaan validoi tuloksia. Lisäksi se valottaa kysymystä, joka on tutkimukseni kuluessa herännyt itselläni ja tullut eteeni myös skeptisinä epäilyinä: miten voi kuulla tunnekokemuksen. Tämä muodostaa myös tutkimuksessani nousevan teoreettis-metodologisen kysymyksen: miten kuulla ja tulkita ero jäljitellyn ja koetusta kumpuavan tunteen ilmenemisen välillä; miten päästä arkistoäänitettä kuunnellen jäljille tunteista, jotka itkijä esitti ja mahdollisesti koki yli puoli vuosisataa sitten?

Ennen analyysiä esittelen itkuvirsiperinnettä, näkökulmani kannalta olennaista aiempaa tutkimusta ja tutkimusaineistoni sekä avaan teoreettista taustaa ja menetelmää, jossa yhdistyvät empaattinen kuuntelu ja auditiivinen äänen analyysi sekä aistietnografinen havainnointi. Kuuntelemisen kokemuksellisuus ja aistietnografia sitovat tutkimukseni myös fenomenologiseen tutkimusperinteeseen. Analyysissa erittelen ensin itkuvirsien tunteita ilmentäviä piirteitä ja niiden tulkitsemista, minkä jälkeen esittelen tunteiden ilmenemisen kannalta erilaisia itkuvirsiä tapausesimerkein, joita havainnollistan graafisilla kuvaajilla ja äänite-esimerkillä. Viimeiseksi erittelen itkuvirsien affektivisuuden eri ulottuvuuksia affektiivisten kehien kautta. Itkuvirsien musiikkia, tekstejä ja näiden yhteyttä tunteeseen ja affektiivisuuteen olen analysoinut aiemmissa artikkeleissani (Silvonen ja Stepanova 2020; Silvonen, tulossa).

\section{Karjalaiset itkuvirret ja aiempi tutkimus}

Karjalaiset itkuvirret ovat naisten esittämää kulttuurisesti koodattua ja siten sosiaalisesti sallittua surun ja kaipuun tunteita ilmentävää, huolia käsittelevää perinnettä. Surun ja kaipuun ohella on kiitollisuutta ja lämpimiä muistoja. Itkuvirret ovat rituaalista kansanrunoutta, ja niillä oli erityisiä tehtäviä riittien onnistumisen kannalta: muun muassa vainajan pääsy tuonpuoleiseen varmistettiin itkuin. Itkijä sepittää itkun esitystilanteessa noudattaen perinteistä ilmaisua ja sommitellen rituaalisia kontekstisidonnaisia ja omaelämäkerrallisia teemoja kulloinkin sopivaksi kokonaisuudeksi. Itkuvirsi ei siis ole ulkomuistista esitetty valmis runo, vaan se muotoutuu joka kerta uudelleen. Itkuvirsien kokonaisilmaisua voi kuvailla tonaaliseksi teksti-improvisaatioksi tai melodiseksi resitaatioksi (Niemi 2002, 694). Aiemmassa tutkimuksessa itkut luokitellaan esitystilanteiden mukaisesti hää-, kuolin-, rekryytti- ja tilapääitkuksi (mm. Nenola-Kallio 1982, 16). Tällainen luokittelu ei näkemykseni mukaan kuvaa itkuperinteen kokonaisuutta mielekkäästi korostaessaan rituaalisia konteksteja ja jättäessään (tunne)ilmaisun ja muut kuin rituaaliset merkitykset huomiotta. Karjalaisesta itkuvirsiperinteestä hahmottuu tyylillisesti toisistaan poikkeavia alueita (Stepanova, A. 2012; Salmenhaara 1976[1967]). Tämä tutkimus keskittyy Aunuksen Karjalan alueeseen, johon lasketaan kuuluvaksi myös Raja-Karjala (kuva 1). (Honko 1963; Konkka 1985; Stepanova, E. 2014.) 


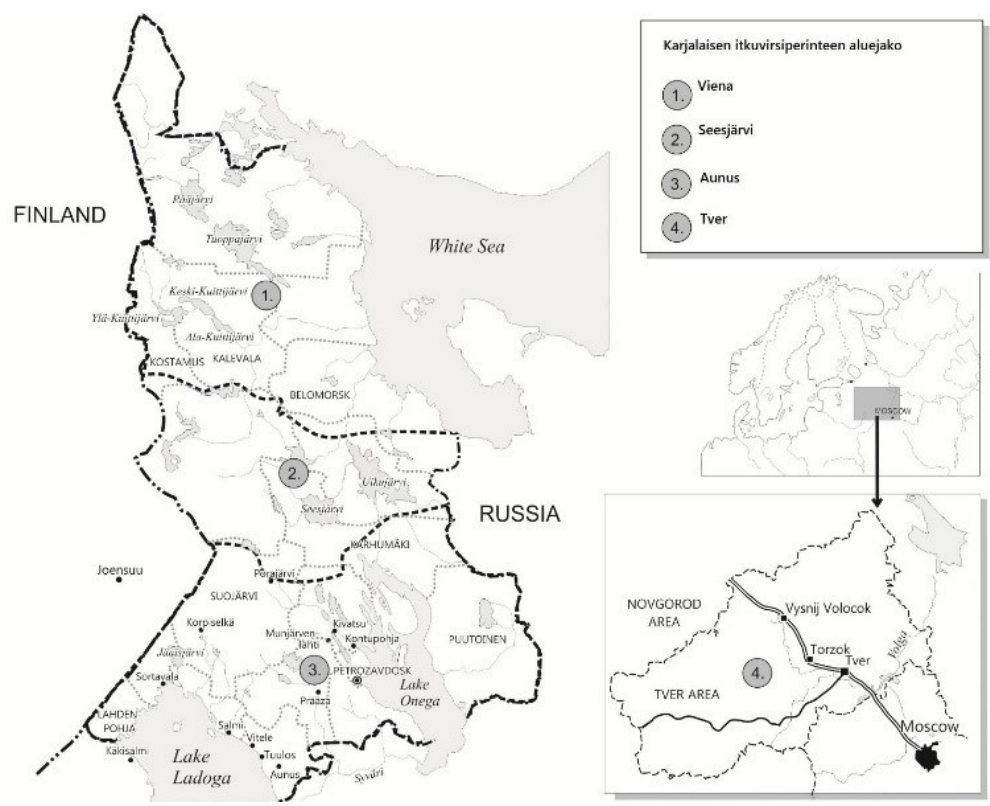

Kuva 1. Karjalaiset itkuvirsiperinnealueet (Stepanova, E. 2014, 286; kartta: Aliisa Priha 2014). Kuvaan ei ole merkitty Suomen puolen ortodoksisia karjalaisia alueilta, joilla itkuperinne tunnettiin (Hakamies 1993; 1995).

Itkuvirsien kieli poikkeaa arkikielestä, ja sen poeettisia erityispiirteitä ovat muun muassa eufemismit, deminutiivimuodot, metaforisuus sekä monitasoinen parallelismi (Honko 1963; Nenola-Kallio 1982; Konkka 1985; Stepanova, E. 2014). Musiikillisesti itkut ovat vähäsävelisiä, eivätkä ne noudata mitään täsmällistä, länsimaisen musiikinteoreettisen näkemyksen mukaista asteikkoa. Säveltasot huojuvat ja fraasien perussävel voi vaihdella yhden itkuvirren sisällä. Kokonaisuudesta hahmottuu toistuva mutta mitaltaan vaihteleva laskevalinjainen melodiasäe, joka on pääsääntöisesti syllabinen ja etenee jokseenkin sävelaskeleittain. (Väisänen 1990[1940-1941]; Salmenhaara 1976[1967]; Gomon 1976; Rüütel ja Remmel 1980; Tolbert 1988; Saastamoinen 1999; Niemi 2002; Silvonen, tulossa). Teksti jää paikoin epäselväksi ääntämisen niin sanotusti puuroutuessa tunteen yltyessä (ks. myös Silvonen, tulossa). Aiemmassa itkujen rakennetta ja musiikkia tarkastelevassa tutkimuksessa itkujen tunneilmaisusta puhutaan nyyhkytysjaksoina tai itkutaukoina, jotka sijoittuvat musiikillisten fraasien väliin (mm. Rüütel ja Remmel 1980, 179; Urban 1988, 389-390; Niemi 2002, 697). Analyysini kuitenkin osoittaa, että nyyhkytykset eivät aina ole selvinä jaksoina tai taukoina, vaan nyyhkytys sijoittuu myös fraasien keskelle (ks. myös Tolbert 1988; Silvonen, tulossa).

Itkuvirsiesitys ilmaisee, esittää ja synnyttää tunteita. Itkiessään äänellä itkijä apeutuu esittämisen kokonaisuuden, ilmaisun, muistojensa, tilanteen ja koko käytännön, vaikutuksesta (Silvonen ja Stepanova 2020; ks. myös Tolbert 1988). Tällainen apeutuminen on tavoiteltua (esim. Kper AK/2940; Honko 1963, 94-97; Konkka 1985). Itkut helpottavat esittäjän itsensä tunnetaakkaa mutta ovat myös yhteisöllinen tunteidenkäsittelyn muoto. Erityisesti rituaalitilanteissa itkijä kanavoi koko yhteisön surua ja toimii ikään kuin esi-itkijänä yllyttäen pintaan omat ja kuulijoidenkin tunteet. Kuulijat ovat esitystilanteessa läsnä olevia muita ihmisiä: rituaalisissa tilanteissa yhteisön jäseniä ja etnografisissa haastattelutilanteissa tallentajia ja mahdollisesti itkijän yhteisön jäseniä. Näiden lisäksi karjalaisissa itkuvirsissä kuulijoina ovat perinteisten myyttisten käsitysten mukaisesti syntyset, joka viittaa yleisesti edesmenneisiin ja tuonpuoleiseen sekä toisinaan myös jumaliin (Stepanova, A. 2012, 188-189). Itkujen 
vastaanottajana on tilanteesta riippuen kulloisenkin rituaalin kohdehenkilö, itkijän läheiset vainajat, kuten äiti tai aviopuoliso, sekä aina läsnä olevana syntyset (Honko 1963; Nenola-Kallio 1982; Konkka 1985; Stepanova, E. 2014).

Aiemmissa itkuvirsitutkimuksissa tunteet ja tunteellisuus mainitaan, mutta tunne ei ole varsinaisesti analysoitavana, vaan keskiössä ovat tekstit, diskurssit ja kontekstit sekä perinne käytäntönä (mm. Honko 1963; Nenola-Kallio 1982; Konkka 1985; Feld 1990; Briggs 1992; Tenhunen, 2006; Stepanova, E. 2014). Keskeisimpiä tunteitakin analysoivia itkututkimuksia ovat Elizabeth Tolbertin etnomusikologinen tutkimus karjalaisista ja inkeriläisistä itkuista (1988; 1990), Greg Urbanin Brasilian alkuperäiskansojen rituaalisen itkuperinteen kommunikaatiota semioottisesti tarkasteleva tutkimus (1988) ja Jim Wilcen tutkimukset nykyitkuperinteestä (2009a; 2011). Nämäkään eivät uppoudu kovin syvällisesti tunteiden ilmenemisen kirjoon eli siihen, mitä itkujen tunteet ylipäätään ovat ja miten tunne ja ennen kaikkea ero tunneintensiteetiltään erilaisten itkujen välillä kuuluu. Urban hahmottelee tutkimuksessaan "luonnollisia" murheen merkkejä (signs of grief) ja kulttuurikohtaisia itkun ikoneita (icons of crying) (mt. 387-391), mikä on jossain määrin saman tyyppinen kuin jaotteluni jäljiteltyyn ja koetusta kumpuavaan tunteen ilmenemiseen. Hän toteaa, että itkuvirret ovat kommunikatiivisesti vakuuttavaa, koska tunteita ilmennetään näyttäen eikä sanallisesti tunteista kertoen (mt. 397; ks. myös Johnstone ja Scherer 2004, 222). Tolbertin laaja tutkimus on lähimpänä omaa aihettani, mutta hänen kiinnostuksensa on erityisesti itkujen symbolisessa merkityksessä. Tunnetta ja sen muutoksia hän tarkkailee mikrotason variaationa hyödyntäen tietokoneanalyysia ja tukeutuen myös neuropsykologiaan. Tolbertin tutkimuksen ongelmiksi hahmotan aineiston maantieteellisen ja ajallisen laajuuden sekä itkuperinteen mystifioimisen, jonka myötä osa tulkinnoista vaikuttaa liian kaukaa johdetuilta. Tolbert muun muassa juontaa itkujen esittämisen euraasialaiseen šamanismiin saakka $(1990,80)$ ja liittää tunneilmaisun ja tunteellisen intensiteetin kohomamisen keinoksi muuttaa tietoisuutta ja saavuttaa transsinkaltainen tila ja siten luoda onnistunut yhteys tuonpuoleiseen $(1990,90)$.

Oman aiemman tutkimuksen mukaan itkijän tunteen yltymisen ja tunteiden välittymisen taustalla vaikuttavat niin kielelliset, tekstilliset, musiikilliset kuin ruumiilliset tunneilmaukset (Silvonen ja Stepanova 2020; ks. myös Tolbert 1988; 1990; Stepanova, E. 2014, 100). Itkujen improvisatorinen luonne, mitallinen säännöttömyys ja monitasoinen parallelismi luovat esitykseen jonkinlaista loputtomuuden ja jatkuvuuden tuntua, ja osittain näiden myötä itkijä voi hiljalleen vaipua syvemmälle tunteisiinsa ja saavuttaa eräänlaisen flow-tilan (Silvonen ja Stepanova 2020, 215; Silvonen, tulossa; ks. myös Margulis 2014, 66-69; Hytönen 2006).

\section{Itkuvirsiaineisto ja lähdekriittisiä huomioita}

Tutkimukseni aineisto koostuu itkuvirsien arkistoäänitteistä, jotka on merkitty aunuksenkarjalaisiksi. Aineisto on tallennettu pääasiassa etnografisissa haastatteluissa useimmiten haastateltavan kotona tai naapurustossa. Koko aineistossani on noin viisisataa itkuesitystä, joista valtaosa on rituaalisia, hää- tai kuolinitkuja. Tarkan tunneanalyysin graafisine kuvaajineen olen tehnyt 104 itkuesityksestä, joista valtaosa on eheitä täysiä esityksiä. Koko aineistokorpuksen varhaisimmat äänitteet ovat 1900-luvun ensivuosikymmeniltä, tunteen kannalta analysoimani itkut on tallennettu vuosina 1940-2001. Koko aineistokorpuksen itkuvirsien täsmällistä lukua on hankala määritellä, koska eri arkistoissa ja eri aikoina äänitteiden sisältöä on luokiteltu eri tavoin etenkin katkelmallisten itkujen osalta. Esitystavat ja esityksen tyyppi vaihtelevat esimerkkikatkelmista niin sanottuihin kokonaisten itkuvirsien täysiin 
esityksiin (ks. Hymes 1975; Bauman 1984), joissa ilmenevät kaikki itkuvirien ominaispiirteet: itkukieli, tekstit ja teemat, sävelmä sekä tunteet. Kokonaisia itkuvirsiesityksiä kutsun eheiksi erotuksena katkelmista. Tämän artikkelin analysoitavan aineiston olen valinnut laajaa aineistokokonaisuutta kuunnellen. Analyysiaineistoni ulkopuolelle jäävät sanellut, sävelmättä esitetyt itkuvirret ja evakkojen keskuudessa tehdyt itkuvirsiäänitykset. Nämä kuitenkin tukevat analyysiani.

Erilaisten esitystapojen lisäksi äänitteiden aineisto on monella muullakin tapaa vaihtelevaa. Tallennustilanne ei vastaa ensisijaisia rituaalisia tai muita yksityisiä äänellä itkemisen tilanteita, mikä vaikuttaa tallennettuun aineistoon monella tasolla (Rüütel ja Remmel 1980, 176; Stepanova, E. 2014, 23-24, 103-105; ks. myös Heinonen 2018, 251-254). Aineiston kirjoon vaikuttavat muun muassa vallitseva tutkimusparadigma ja sen myötä tutkimusintressit, kysymyksenasettelu ja haastattelutyyli, tekniset seikat, yleinen tunnelma sekä kunkin itkijän yksilöllinen tapa ja motivaatio esittää arkaluonteista perinnettä. Äänitetty materiaali vaihtelee pelkistä itkuvirsistä koko haastatteluihin. Teknologian kehittyminen fonogrammiäänitteistä kelanauhureihin helpotti äänitystä ja mahdollisti pitemmät yhtäjaksoiset äänitykset, mutta nauhat olivat kalliita ja käytettävissä oleva määrä vaihteli paljon. Toisinaan äänitys tai äänite katkeaa kesken itkun ilman selitystä siitä, onko kyseessä tekninen vika, haastateltavan pyyntö vai haastattelijan päätös (vrt. Heinonen 2008, 239). Joissain tapaukissa syitä katkeamiseen voi päätellä äänitteeltä. Esimerkiksi joissain tapauksissa vaikuttaa siltä, että äänite katkaistaan itkijän apeutuessa (SKS KRA A 886/20; SKS KRA A 375/5 1958; Fon.144/2). Äänitteillä kuuluu usein myös pientä häiriöääntä tai tallennustilanteessa ollutta taustahälinää, mikä ei haittaa analyysiani. Osa etenkin 1900-luvun alkuvuosikymmenten äänitteistä on kuitenkin teknisesti niin heikkoja, ettei niistä ole aineistoksi tunneanalyysiin, kun häiriöäänten seasta on mahdotonta erottaa tunteen ilmenemiseen liittyviä äänenpiirteitä.

Lisäksi tallenteiden metatiedoissa on puutteita: auki jää ketkä kaikki ovat olleet paikalla haastattelutilanteessa, missä tallennus on tehty tai mikä on haastateltavan ja haastattelijan/ haastattelijoiden välinen suhde. Jotkin näistä on pääteltävissä äänitteiltä, mutta ei kaikki. Haastattelijan lähestymistavat vaihtelevat paljon. Toiset lähestyvät aiheita laveammin johdatellen ja toiset pyytävät suoraan äänellä itkemään. Toisinaan haastattelija pyytää ensin vain sanelemaan itkuvirttä ja sitä kautta lämmitellä itkijää täysiin esityksiin. Haastattelijan tyyli sekä haastattelijan ja haastateltavan välinen vuorovaikutus vaikuttavat suoraan tallennustilanteen ilmapiiriin, joka vaikuttaa edelleen itkuvirsien esittämisen tapaan. Jotkut haastattelijat luovat apeutumiselle ja henkilökohtaisille aiheille sopivaa tunnelmaa kysellen haastateltavan perheestä ja elämästä, siten päästen hääitkuihin tai kuolin- ja muisteluitkuihin. Keskeisessä asemassa on myös itkijän oma motivaatio esittää itkuvirsiä ja näkemys siitä, minkälainen esitys on kussakin tilanteessa sopiva. Itkuperinteen arkaluonteisuus liittyy itkujen aiheiden henkilökohtaisuuden lisäksi itkuperinteen myyttiseen taustaan: rituaalisen perinteen esittämisen epätavallisessa esitystilanteessa ja niin sanotusti tarpeeton äänellä itkeminen saattoivat aiheuttaa harmiakin (esim. Konkka 1985, 12). Itkijät ovat voineet välttää apeutumista haastattelutilanteissa myös sen fyysisen ja psyykkisen raskauden vuoksi (esim. SKNA 7592:3; SKNA 7593:1). Usein äänitteillä on pitkiäkin pätkiä, kun haastattelija koettaa suostutella haastateltavaa esittämään itkuvirsiä. Etenkin näissä tilanteissa tulevat esiin myös itkijöiden vaihtelevat temperamentit, kun yksi pistää vastaan päättäväisesti (esim. Fon.2781a/1-3) ja toinen vaikuttaa arastelevan (esim. SKNA 10114:2). Kaikki nämä tallennustilanteen tekijät vaikuttavat suoraan siihen, mitä voin äänitteellä kuulla ja miten tulkitsen äänitteitä. Vaikka arkistoäänitteiden itkuvirsiä ei ole äänitetty ensisijaisissa ja siltä 
kannalta autenttisissa äänellä itkemisen tilanteissa, voi haastattelutilanteessa esitetty itkuvirsi olla esityksenä täysi ja syvästi apeutunut itkuvirsiesitys (ks. myös Stepanova, E. 2014, 97-98; vrt. Rüütel \& Remmel 1980, 176).

Ymmärrykseni itkuvirsistä perustuu monivuotiseen aineistokokonaisuuden tarkasteluun eri näkökulmista. Koko tutkimusprosessini kuluessa olen kuunnellut aineistoni itkuja useaan kertaan kirjaten muistiin tutkimusintresseihini liittyviä seikkoja niin itkuvirsistä, esittämisestä kuin äänitekontekstista eli itkuja ympäröivästä keskustelusta ja muista esityksistä. Nämä "kenttäpäiväkirjat" ovat osa aineistoani, kun olen vertaillut eri kuuntelukertojen tulkintoja, jotka vaihtelevat kulloisenkin päähuomion kohteen mukaan (vrt. Silvonen ja Stepanova 2020; Silvonen, tulossa).

\section{Tunne ja affektiivisuus}

Tunne on monimuotoinen ilmiö, jolla ei ole itsessään erillistä "olemusta" (Kivikangas 2015, 29; myös Barrett 2017, 12-16) ja jonka määritelmä vaihtelee paljon eri yhteyksissä. Humanistis-yhteiskuntatieteellisillä aloilla vallitsee melko laajasti yksimielisyys siitä, että tunneilmaisu ja -kokemus kietoutuvat toisiinsa ja tunteet ovat ruumiillisia ja siten subjektiivisia sekä sosiaalisia (esim. Wilce 2009a, 43; Wetherell 2012, 2-22; Scheer 2012, 195-209; myös Newell $2018,2,13,17)$. Affekti- ja tunneteorioiden eri suuntauksissa on kuitenkin myös useita ristiriitoja. Esimerkiksi käytetyt käsitteet ja niiden määritelmät vaihtelevat, minkä seurauksena näkökulmien hahmottuminen mutkistuu. Osa tutkijoista viittaa koettuun tunnetilaan affektin käsitteellä (esim. Wetherell 2012, 4), toisissa näkemyksissä tunnekokemukseen viitataan emootion käsitteellä ja affekti puolestaan viittaa kappaleiden väliseen affektiiviseen intensiteettiin (esim. Massumi 1995, erit. 88-89, 96). Erojen taustalla on eriäviä tutkimusintressejä ja näkemyseroja tunteiden ontologiasta, kuten hahmottuuko tunne yhtenäisenä kokonaisuutena (esim. Wilce 2009b; Wetherell 2012; Scheer 2012), vai erottuuko siitä eri puolia, kuten Brian Massumin (1995) affekti esisemioottisena intensiteettinä ja emootio laadullisesti tulkittuna kokemuksena (ks. myös ks. Wilce 2009b, 28-32, 35-38; Salmela 2017). Tutkimusasetelmani eri ulottuvuuksiin vastatakseni olen muodostanut synteesin lukemalla lomittain eri alojen ja tutkijoiden näkemyksiä siitä, mitä tunteet ovat ja miten ne muodostuvat, ja tarkkaillut näiden näkemysten tiedonintressejä, yhtymäkohtia ja ristiriitoja (mm. Massumi 1995; Johnstone ja Scherer 2004; Wilce 2009b; Ben-Ze'ev 2010; Wetherell 2012; Scheer 2012; Kivikangas 2015; Mendes 2016; Barrett 2017; Newell 2018; myös Urban 1988; Tarvainen 2012). Analyysini eri vaiheissa jäsennän tunnetta tutkimuskirjallisuuden pohjalta toisistaan poikkeavin ja paikoin ristiriitaisinkin näkemyksin, kun hahmotan tunteen kokonaisvaltaisena ilmiönä, jota kuitenkin tarkastelen kokonaisuuden eri puoliin fokusoiden tunnekokemuksena ja tunteen ilmenemisenä sekä affektiivisena intensiteettinä.

Tutkimuksessani ymmärrän tunteet monimuotoisena kompleksisena ilmiönä, ikään kuin kudelmana, jossa kokonaisuuden syntymiseen vaikuttavat kulttuuriset, sosiaaliset, psykologiset, biologiset ja fysiologiset tekijät. Ymmärrykseni rakentuu etenkin tunneilmiön kokonaisvaltaisuutta, kognition, kokemuksen, ruumiillisuuden, kulttuurisuuden ja sosiaalisuuden yhteyttä, painottaville näkemyksille (Wetherell 2012; Scheer 2012; ks. myös Newell 2018; ks. myös Barrett 2017). Käytän tunnetta yleisenä terminä viittaamaan koko ilmiöön. Tunne-termin ongelmana on sen osin arkikielestäkin nouseva laveus ja hämäryys, joten selvennän määritteillä, mistä milloinkin on kyse. Tunnekokemus ja koettu tunne tai tunnetila viittaavat niin sanotusti yksilön sisäisiin tiloihin. Hahmotan tunnekokemuksen subjektiivisena tilana, 
joka syntyy, välittyy ja tulee merkitykselliseksi vuorovaikutuksessa sosiaaliseen, kulttuuriseen ja biologiseen kontekstiin (Wetherell 2012, 4, 9-25; Barrett 2017, 16; Newell 2018, 2, $13,20)$. Tunteen ilmeneminen on puolestaan ulospäin näkyvää joko tarkoituksellisesti tuotettua, stereotyyppistä ja jäljitellen esitettyä tai tahdosta riippumatonta, koetusta kumpuavaa (Johnstone ja Scherer 2004, 221-222; ks. myös Urban 1988, 387-391).

Tunteesta erillisenä, vaikka tunteeseen kokonaisilmiönä liittyvänä, hahmotan affektiivisuuden, jossa painottuvat ruumiillinen vaikuttuminen ja kappaleiden välinen intensiteetti (Massumi 1995, 88-89, 96; Newell 2018, 2, 13, 20; Slaby 2018, 198-199; ks. myös Wetherell 2012, 2-4, 74-75). Tunteeseen nähden affektiivisuus on määrittelemätöntä intensiteettiä ja välisyyttä, ja se vertautuu jossain määrin yleiskielen liikuttumiseen tai herkistymiseen. Affektiivisuus ei ole tunteiden siirtymistä tai tarttumista. Kappaleiden välistä intensiteettiä korostava näkemys mahdollistaa monenlaisia sovelluksia, joissa huomio ei kiinnity vain inhimilliseen kokemiseen vaan myös erilaisiin objekteihin kiinnittyvään affektiivisuuteen (esim. Povrzanović Frykman 2016; Newell 2018; ks. myös Wetherell 2012, 75; Slaby 2018, 198). Lähestyn äänellä itkemisen moniulotteista affektiivisuutta tällaisen välisyyden ja intensiteetin näkemyksen kautta: tarkastelen affektiivisuutta muun muassa itkijän ja itkuvirren sekä arkistoäänitteen itkuvirsiesityksen ja kuuntelijan välillä. Itkuvirsiesityksessä syntyviä erilaisia liikutuksen, tunteiden yltymisen, apeuden välittymisen ja tunteista vaikuttumisen ilmiöitä, joiden vaikutuspiirissä ovat niin esittäjä kuin kuulijatkin, tarkastelen affektiivisina kehinä (vrt. Slaby 2018; 2019, 109).

\section{Tunne koettuna, ilmaistuna ja tulkittuna}

Tunteiden - niin omien kuin toisten - tunnistamisessa ja tulkitsemisessa vaikuttavat kognitiiviset arviot sekä ruumiillinen ja kokemuksellinen tieto (esim. Ben-Ze'ev 2010, 5-13; Mendes 2016, erit. 169-170, 174-178; Barrett 2017, 12-14; ks. myös Wilce 2009a, 43-44; Wetherell 2012, 4; Scheer 2012). Kognitiivinen, ruumiillinen ja kokemuksellinen eivät ole toisilleen vaihtoehtoisia, vaan ne kytkeytyvät toisiinsa (Noë 2009, 10; Scheer 2012; Pink 2015, 25-32). Psykologiset ja fysiologiset prosessit, kulttuuriset ja sosiaaliset mallit ja henkilökohtaiset kokemukset ja tavoitteet vaikuttavat tunnekokemuksen synnyn lisäksi tunteiden ilmaisemissa, jossa sekoittuvat tarkoituksellisesti tuotetut ja koetusta kumpuavat tunteen tunnukset ja joka on kommunikatiivista (ks. myös Johnstone ja Scherer 2004, 221-222; Wilce 2009a, 43-44; Scheer 2012, 195).

Näkemykseni mukaan tunnekokemus ja tunneilmaisu kietoutuvat toisiinsa empirian tasolla, mutta eivät ole erottamattomat: tunteen ilmaisemisen taustalla ei aina ole ilmaisua vastaava tunnekokemus, vaan ilmaisu voi perustua vain tiettyjen tunnetta ilmentävien tunnusten jäljittelemiseen (vrt. Tarvainen 2012, 90, 109). Koetusta kumpuava tunteen ilmeneminen vaikuttaa siihen, minkälaisia ilmaisullisia tunteen tunnuksia mihinkin tunteeseen liitetään, ja sitä kautta siihen, miten jotakin tiettyä tunnetta esitetään. Tunteiden esittäminen eli ilmentäminen vain tunteen tunnuksia jäljittelemällä voi ruokkia tunnekokemusta (Levenson 2003, 350-353; Johnstone ja Scherer 2004, 222). Äänellä itkiessä itkijän jäljitellen esittämät tunteen tunnukset voivat yllyttää hänen tunnetilaansa (ks. myös Tolbert 1990, 99; Silvonen ja Stepanova 2020, 216-218).

Käsitteinä ilmaisu ja tulkinta ovat monitulkintaisia. Ilmaisulla tarkoitan jokseenkin neutraalia tekoa, asioiden ilmi tuomista jollakin tietyllä tavalla. Ilmaisu on ainakin jossain määrin 
tietoista toimintaa. Tulkita on tutkimuksessani nimenomaan vastaanottajan toimintaa, välittyvän viestin tunnistamista, tulkintojen tekemistä, ei siis 'tulkinta' ymmärrettynä kuten lauseessa: laulaja on valovoimainen tulkitsija (vrt. Tarvainen 2012, 21). Äänellä itkemisen käsitän rituaalisena käytäntönä ikään kuin suorempana ilmaisuna kuin tulkitseminen. Itkuvirsi ei ole laulu, eikä itkuvirsien esittämistä karjalaisessa kulttuurissa nimitetty laulamiseksi (pajattamiseksi) vaan virzittämiseksi (Stepanova, E. 2014, 99), eänelitkemiseksi tai vain itkemiseksi (Konkka 1985, 10). Itkijä ei tulkitse itkuvirttä, hän itkee äänellä. Itkijä ei myöskään tulkitse tunteita, vaan ennemminkin hän äänellä itkiessään esittää ja mahdollisesti kokee niitä.

Itkuvirressä tunteet ilmenevät eli tulevat pintaan koetusta kumpuavina ja jäljiteltyinä, jotka molemmat ovat tunteen merkkejä ja ne saavat erilaiset tulkinnat (vrt. Visakko 2015, 29-30). Tunnetta kommunikatiiviselta kannalta tarkasteltaessa kontrolloimattomat, "raa'at" (Johnstone ja Scherer 2004, 222) tunteen tunnukset, joiden juurena on "puhdas affektiivinen kokemus" (Urban 1988, 397) neuropsykologisine prosesseineen, tulkitaan uskottavampina ja aidompina kuin muunlainen tunteiden ilmeneminen (esim. Urban 1988, 397; Johnstone ja Scherer 2004, 222; ks. myös Tarvainen 2012, 106-108). Lauluntutkimuksen puolella vastaavan tyyppistä jaottelua on tehty "tyhjiin" ja "täysiin" tunnemaneereihin sen mukaan, onko kyseessä pelkkä "tunteen stereotyyppinen tunnuskuva" vai liittyykö siihen myös "aidosti läpieletty tunne" (Tarvainen 2012, 108). Tunteen aitouteen liittyviä samoin kuin kokemuksen ja ilmaisun erottavia näkökulmia on kritisoitu luonnollisen tai biologisen ja kulttuuris-sosiaalisen vastakkainasettelusta (esim. Wilce 2009b, 9, 28-30; Scheer 2012, 207, 214-215; Wetherell 2012, 17-19).

Käytäntönäkökulmasta tunteen ilmenemisen eri puolet, jäljitelty ja koetusta kumpuava, hahmottuvat genren mukaisina, autenttisina ja oikeina itkuvirren piirteinä, joten jäljitellyn ja koetusta kumpuavan välinen erottelu ei autenttisuusmielessä ole olennaista. Tutkimukseni kuitenkin osoittaa, että näiden erottaminen on keskeinen väline affektiivisuuden analyysissa ja hahmotettaessa tunteellisesti erilaisia itkuvirsiä (vrt. Urban 1988, 389). Aineistossani jäljitellyn ja koetun välinen ero kuuluu jokseenkin selvästi: useissa itkuissa itkijä korvin kuullen apeutuu itkuvirren edetessä (esim. SKNA 7592:3/JFS2; Fon.885b/13: ks. myös Silvonen ja Stepanova 2020). Jäljitellyn ja koetusta kumpuavan tunteen ilmenemisen erottelu perustuu hienovaraisiin äänenlaadun muutoksiin (ks. myös Tolbert 1988; 1990; Tarvainen 2012, 109), joiden tulkinta on tapauskohtaista.

Tunteen sosiaalisia ulottuvuuksia, kuten tunteiden tunnistamista sekä affektiivisuuden ja tunteiden välittymistä, lähestytään eri alojen tutkimuksissa vaihtelevin teorioin muun muassa välittymisen, siirtymisen ja tarttumisen käsittein sekä ruumiin peilaavuuden kautta (esim. Wetherell 2012, 141-152; Tarvainen 2012, 142-143; Daly 2016, 193-197). Vaikka en tarkastele varsinaista tunteiden tarttumista, täydentävät nämä näkökulmat ymmärrystäni affektiivisuudesta niin itkutilanteessa läsnä olevien ihmisten välillä kuin arkistoäänitteen kuuntelemisessa. Itkuvirsien tunteiden tunnistamista ja tulkintaa hahmotan myös performanssiteoreettisesti tulkintakehyksen (Bauman1984, 9-10) ja esitysareenan (Foley 1995, 8) käsittein: osallistujien toimintaa ja tulkintojen tekemistä ohjaavat kulttuuriset ja sosiaaliset konventiot ja odotukset (myös Siikala 1984, 219-220; Stepanova, E. 2014, 45, 101). 


\section{Auditiivinen äänen analyysi ja empaattinen kuuntelu aistietnografian kehyksessä}

Tutkimukseni analyysi on aineistolähtöinen ja moniulotteinen, ja menetelmässä eri analyysivaiheet ovat päällekkäisiä ja risteäviä. Analyysimenetelmäni rakentuu kahdenlaisesta analyyttisesta kuuntelemisesta, auditiivisesta äänen analyysista ja empaattisesta kuuntelusta (Tarvainen 2012), joissa hyödynnän myös omia kokemuksiani. Tutkimuksessani kokemuksellisuus kehystyy tunne- ja affektiteorioihin sekä aistietnografiaan (Pink 2015), jonka lähtöpisteenä on etnografisen ja autoetnografisen näkökulman yhdistäminen sekä kokemisja aistimisperustainen tietäminen. Kokemuksellinen lähestymistapa auttaa ymmärtämään affektiivisuuden ja tunteiden ilmenemisen moniulotteisuutta ja vaihtelevuutta. Kokeminen ei ole vain subjektiivista, vaan se rakentuu kanssakäymisessä kaiken ympäröivän kanssa, joten kokemista on lähestyttävä sekä subjektiivisena että intersubjektiivisena aistimisena eli reflektoitava sekä subjektiivisuutta että sosiaalisia ja kulttuurisia suhteita. (Pink 2015, 58-65.) Oman kokemuksen analyysi ei anna yleistettävää tietoa, vaan kokemiskeskeinen (aistietnografinen, fenomenologinen) lähestymistapa lisää ymmärrystä siitä, miten merkityksiä muodostuu, annetaan ja välittyy kulloisessakin sosiaalisessa ja kulttuurisessa kontekstissa (Tarvainen 2012, 29, 36-40; Pink 2015, 25-32, 58-65; myös Scheer 2012, 207).

Auditiivisen äänen analyysin ja empaattisen kuuntelun voi ajatella eräänlaisena äänitallenteen lähilukemisena (vrt. Tarvainen 2012, 42, "kontemplatiivinen kuunteleminen"). Kaksivaiheisessa kuuntelumenetelmässä esitystä lähestytään "redusoivan kuuntelemisen ja fokusoimisen avulla" eli huomioimalla yhtä tasoa kerrallaan siinä määrin, kun toisen voi sulkea pois (Tarvainen 2012, 105-106). Auditiivisessa äänen analyysissa erittelen tunneilmaisuun liittyviä äänenlaadun piirteitä ja hengitystä, minkä taustana ja tukena kiinnitän huomiota joihinkin yksilöllisiin piirteisiin, kuten äänen voimakkuuteen ja äänentuoton tapaan (äänirekisteri: kuiskaava, ohenteinen, falsetti, rintaääni). Tutkimuksessani empaattinen kuuntelu on kokonaisvaltaisesti affektiivisuudelle avointa kuuntelemista. Empaattisessa kuuntelussa tarkastelen itkuvirsien affektiivisuutta oman kuuntelukokemukseni ja aistimisen kautta; havainnoin niitä itkuvirren kohtia, jotka ikään kuin vetävät huomioni jollakin tapaa ympäröivää intensiivisemmin puoleensa ja saavat minut tiiviimmin kuuntelemaan. En analysoi omia tunteitani, vaan aistimukseni ja kuuntelemisen intensiteetin muutokset ovat analyysivälineenä, kun selvitän itkuvirsien affektiivisuutta. (Vrt. Heinonen 2008, 248-249.)

Kuuntelumenetelmäni on osittain sovellus Anne Tarvaisen käyttämästä kolmivaiheisesta analyyttisestä kuuntelusta (2012, erit. 40-42, 199-247), mutta olen muodostanut menetelmäni oman tutkimusintressini ja aineistoni ehdoilla. Tarvainen analysoi laulajan ääntä, ilmaisua ja tulkintaa Björkin Vespertine-albumilla etnomusikologisessa, fenomenologisessa sekä äänen- ja ilmaisuntutkimuksen kehyksessä. Hänen menetelmänsä on kaikkiaan omaani fysiologisempi. Tarvainen erottaa empaattisen ja analyyttisen kuuntelun lisäksi eläytyvän kuuntelemisen. Tarvaisen empaattisen kuuntelun menetelmässä painottuvat "kuuntelukokemuksessa esiin tulevien kehollisten laatujen sanallinen kuvailu", "äänellinen imitointi sekä graafisen kuvauksen tekeminen" (mt. 41), kun taas eläytyvä kuuntelu on "kaiken sallivaa ja kokonaisvaltaista" (mt. 201). Tutkimukseni empaattinen kuuntelu asettuu ikään kuin Tarvaisen eläytyvän ja empaattisen kuuntelun rajamaastoon ja yhdistyy myös puheviestinnän ymmärrykseen, jossa empaattisella kuuntelemisella viitataan puhujan tunteita heijastavaan ja puhujan näkökulmaa ymmärtävään kuuntelemisen tapaan (Drollinger et al. 2006, 161164; Tarvainen 2012, 204, alaviite 235). 
Tunnepiirteiden kuuntelemisen taustaksi olen analysoinut omaa itkemistäni (ei äänellä itkemistä vaan kyynelin itkemistä) ja surun kokemuksiani tunneteorioiden valossa ja luonut näin niin sanotusti ruumiillista esiymmärrystä itkemisestä (vrt. Tarvainen 2012, 209-210). Olen kiinnittänyt huomiota siihen, miltä kaikelta itkeminen ja erilaiset tunnekokemukset kuulostavat, miten koko ruumis reagoi ja miten reaktiot vaikuttavat välittyvään kuuluvaan ääneen - ei fysiologiseen äänenmuodostumisen prosessiin, vaan minusta kuuluvien äänien ominaisuuksiin. Samalla tiedostan, että nuorena nykytutkijana sosiaalinen, kulttuurinen ja biologinenkin kontekstini sekä tapani luokitella ja käsitteellistää aisti- ja tunnekokemuksia ovat erilaiset kuin karjalaisessa yhteisössä eläneillä itkijänaisilla. Eroista huolimatta, synteesinä edellä käsitellystä tutkimuskirjallisuudesta ajattelen, että omille ja menneisyyden itkijöiden tunnekokemuksille yhteistä ovat jotkin fysiologiset tekijät ja niiden vaikutus ääneen, näiden äänten yhdistäminen surun kokemukseen tulkintakontekstin mukaan sekä kokemuksen monivivahteisuus.

Itkuvirsien tunneanalyysin eri vaiheet eivät asetu lineaarisesti peräkkäin vaan liikun niiden välillä myös edestakaisin, näin koko metodista muodostuu eräänlainen analyysivaiheiden ja -menetelmien verkosto. Empaattisen kuuntelun ja auditiivisen äänen analyysin vaiheet vuorottelevat, ja näiden kummankin havainnot vaikuttavat toisiinsa. Vaikka empaattisessa kuuntelussa pyrin häivyttämään analyyttisen suhtautumisen ääneen, ovat aiempien kuuntelukertojen analyyttiset havainnot äänenlaaduista välttämättä taustalla. Auditiivisessa äänen analyysissa erittelen ja kokoan itkuvirsistä äänenpiirteitä, jotka tulkitsen empaattiseen kuunteluun nojaten liittyvän itkuvirsien tunteisiin joko jäljiteltynä tai koetusta kumpuavana (ks. taulukko 1 analyysissa). Tunteen ilmenemistä yksittäisissä itkuvirsissä kuvaan graafisesti janoilla, joihin kokoan kuunteluanalyysieni havainnot (kuvat 2 ja 3 tapausesimerkkien analyysissä.) Merkitsen ensin auditiivisen analyysin piirteet, jonka jälkeen täydennän kuvaajaan tulkitsemani intensiteetin kohoamiset ja muita tulkinnanvaraisia affektiivisuuteen viittaavia piirteitä. Empaattisen kuuntelun aluksi vain kuuntelen itkuvirren ja kirjaan yleisvaikutelman, jonka jälkeen kuuntelen äänitteen uudelleen tehden merkintöjä itkujanalle. Empaattisen kuuntelun kohtien vertaaminen auditiivisen analyysiin piirteisiin osoittaa itkuvirren äänelliset piirteet, joiden tulkitsen ilmentävän tunnetilan muutosta. Kuunteluanalyysissa hahmottuu myös, mitä kaikkea tunne itkuvirsissä on ja miten itkuvirsien tunteiden eri tasot suhteutuvat toisiinsa. Yksittäisten itkuvirsien tunneanalyysissa kuuntelen itkuja äänitekontekstista irrallaan, mutta tulkinnassa tukeudun tarvittaessa myös tähän kontekstiin. Omien kuunteluanalyysivaiheiden jälkeen kuuntelutan itkuvirsiä vertailuryhmälle. Vertailuhaastattelu validoi omia analyysejani, ja paljastaa, miten itkuvirsien affektiivisuus välittyy kuuntelioille, jotka eivät tunne itkuvirsien kulttuurisia merkityksiä ja esittämisen tavoitteita. Analyysin viimeisenä vaiheena tulkitsen analyysin eri osien ja analyysitasojen tuloksia reflektoiden sosiaalisia ja kulttuurisia suhteita ja hahmotellen erilaisia affektiivisuuden ilmiöitä ja vaikutusaloja affektiivisina kehinä (kuva 4 analyysissa).

Vertailuryhmän haastattelut järjestettiin kotioloissa kesällä 2020. Haastateltavat kuuntelivat itkuvirsiäänitteen ja kertoivat vapaasti, mitä kuunteleminen heissä herätti. Haastateltavat tiesivät, että tutkimuksessa tarkastellaan itkuvirsien tunteita, mutta ohjeistin heidät kuuntelemaan avoimesti eikä niinkään tunteisiin keskittyen. Koska oletin, että kuuntelu ei välttämättä herätä tunteita tai että tällainen suora kysymys voisi rajoittaa kommentointia, avasin keskustelun kysymällä: "Minkälaisia ajatuksia tai filiksiä kuunnellessa heräsi?" Haastatellessani välttelin johdattelevia kysymyksiä ja kommentteja ennen kuin kuuntelija oli kertonut 
ja kommentoinut kuulemaansa. Haastatteluissa käytin samoja itkuvirsiä, jotka olen valinnut tapausesimerkeiksi artikkeliin. (Tarkemmat tiedot, ks. Liite 1.)

\section{Itkuvirsien tunteet ilmenevänä, kuunneltuna ja välittyvänä}

Itkuvirsien tunteen ilmenemiseen, sen tunnistamiseen ja affektiivisuuteen liittyvät olennaiset piirteet muodostavat karkeasti kolme ryhmää. Näistä kaksi ensimmäistä ovat affektiivisuuden kuuntelijalle välittymisen kannalta merkittäviä (taulukko 1) ja kolmas näitä tukeva. Ensimmäisen ryhmän muodostavat äänen piirteet tai ominaisuudet, jotka toistuvat aineistossani yleisesti ja liittyvät usein toisiinsa. Näitä piirteitä ovat voimakas uloshengitys, korostunut, puuskahtavasti lausuttu äänne, kuuluva sisäänhengitys, nariseva sisäänhengitys, vuotoinen, ohentuva ääni, jännitteinen, tukahtuva ääni, epävakaa, huojuva ääni, katkeileva ääni sekä nyyhkäykset, niiskaukset ja varsinainen itku. Näiden äänenpiirteiden taustalla vaikuttavat erilaiset fysiologiset muutokset. Osa näistä on genretyypillisiä piirteitä, jotka ovat sosiaalisesti ja kulttuurisesti jaettuja, ne ovat leimallisia koko itkuperinteelle, vaikka kaikki itkijät eivät kaikkia niitä käytäkään (vrt. keys of performance, Bauman 1984, 15-24; ks. myös Urban 1988). Toiset ovat puolestaan yleisempiä mutta leimallisia myös äänellä itkemiselle. Edellä listattujen piirteiden lisäksi tunteet ja tunneintensiteetin muutos ilmenevät myös muina äänenpiirteinä. Esimerkiksi itkun virrassa itkijän äänenväri voi muuttua yleisellä ja kokonaisvaltaisemmalla, tarkemmin määrittelemättömällä tavalla joko hetkellisesti tai pidemmäksi aikaa. (Vrt. Urban 1988; 389-391; Tolbert 1990, 99; Johnstone ja Scherer 2004, erit. 226-232; Tarvainen 2012, 223-228.) Toisen ryhmän muodostavat yleisen tason piirteet, jotka kuuluvat auditiivisessa äänen analyysissa, mutta joiden merkitykset ovat tulkinnanvaraisempia. Näitä piirteitä ovat yleinen esityksen intensiteetin kohoaminen, tarkemmin määrittelemätön valittava, itkeväksi tulkittu tai itkemistä jäljittelevä ääni sekä hymyilyksi tai naurahdukseksi tulkittu ääni. Etenkin voimakas itkemisen jäljittely vaikuttaa kääntyvän helposti naurunkin puolelle (esim. Fon.985/4). Erityisesti näiden piirteiden tulkitsemisessa ja tunnistamisessa vaikuttaa empaattinen kuuntelu.

Taulukko 1. Affektiivisuuden analyysissa tarkastellut piirteet ja graafisten esitysten merkit.

\begin{tabular}{|c|c|}
\hline Affektivisuuden välittymisen ja tunteen tulkinnan kannalta merkittävät piirteet & merkki \\
\hline \multicolumn{2}{|l|}{ ensisijaiset analysoitavat piirteet } \\
\hline voimakas uloshengitys, äänteen yhteydessä ilmaa ulos & $\mathrm{H} \rightarrow$ \\
\hline korostunut, puuskahtavasti lausuttu äänne (edeltävää voimakkaampi) & $>$ \\
\hline kuuluva sisäänhengitys, haukkova henki & $\mathrm{H} \leftarrow$ \\
\hline nariseva sisäänhengitys & $\mathrm{Hn} \leftarrow$ \\
\hline vuotoinen, ohentuva ääni, muutokena yleiseen & --- \\
\hline kireä, jännitteinen, tukahtuva tai puristunut (mutta ei paineisesti ulos työnnetty) ääni & $1-1$ \\
\hline epävakaa ääni, huojunta & $\sim \sim$ \\
\hline katkonainen ääni & $-|-|-$ \\
\hline nyyhkäys, niiskaus, itkemisen ääni & $\mathrm{N}$ \\
\hline yleinen, kokonaisvaltainen äänenvärin muutos & M \\
\hline \multicolumn{2}{|l|}{ tulkinnanvaraiset piirteet } \\
\hline yleinen affektiivisuuden nousu, intensiteetin voimistuminen (oma kuuntelukokemus tulkinnassa) & + \\
\hline määrittelemätön, itkua jäljitteleväksi tai itkemiseksi tulkittu ääni & ............ \\
\hline nauruksi, naurahdukseksi, hymyilyksi tulkittu ääni & $*$ \\
\hline
\end{tabular}


Kolmannen, väljemmin hahmottuvan ryhmän muodostavat piirteet, joilla on vaikutusta kuuntelijan tilannekohtaiseen tulkintaan mutta jotka ovat esittäjästä ja esityskerrasta riippuvia ja vaihtelevia. Näitä piirteitä ovat yleinen äänentuoton tapa (esim. äänirekisteri, kuten falsetti ja kuiskaus), äänen voimakkuus, tempo ja mahdolliset pitemmät tauot. Etenkin äänirekisterillä ja jossain määrin voimakkuudellakin on vaikutusta myös ensimmäisen ryhmän piirteisiin. Kolmannen ryhmän piirteet ovat tulkintaa tukevia eivätkä siis analyyttisen erittelyn kohteena. Aiemmassa tutkimuksessa myös äänenkorkeuden nousu tai rekisterin vaihtuminen falsettiin yhdistetään toisinaan tunneintensiteetin kohoamiseen (Tolbert 1990, 100-101), mutta aineistossani tällaisesta ei ole selviä viitteitä.

Kaikkien piirteiden ilmeneminen ja käyttö ovat itkuesityksissä yksilöllisiä. Kunkin itkijän henkilökohtainen tyyli, vaihtelevat esitystavat ja esitystilannekohtaiset erot vaikuttavat paljon siihen, miltä itkuvirsi milloinkin kuulostaa ja miten sen milloinkin tulkitsee. Ensimmäisen ja toisen ryhmän elementtien tulkinta on genrekohtaisesti ja kulttuurisesti koodattua ja ainakin kompetenttien esittäjien ja kuuntelijoiden kesken jaettua. Kaikki eri piirteet vaikuttavat esityksen yleisen affektiivisen intensiteetin kohoamiseen ja apeutumiseen sekä näiden tulkintaan ja välittymiseen. Mikään yksittäinen piirre ei kerro apeutumisesta, vaan tulkintaan vaikuttaa esitys kokonaisuudessaan ja sen monitasoinen tulkinta (vrt. Stepanova, E. 2014, 100).

Yksi ja sama äänenpiirre voi samassa itkuvirressä ilmetä koetusta kumpuavana tai jäljiteltynä tunteen tunnuksena. Esimerkiksi kuuluva nyyhkäys voi itkuesityksen alkupuolella olla jäljitelty, mutta itkijän tunnetilan yltyessä kuuluvat nyyhkäykset voivatkin tulla tulkituiksi koetusta kumpuavina. Jäljitellyn ja koetusta kumpuavan tunteen ilmenemisen erottelu on affektiivisuuden analyysin ja sitä kautta tunteen ilmenemisen kannalta erilaisten itkuvirsien hahmottamisessa keskeinen. Tulkinta on useimpien piirteiden kohdalla varsin häilyvää. Häilyvyyttä lisää se, että kokemuksesta nousevat piirteet eivät välttämättä nouse apeuden kokemuksesta. Esimerkiksi kontrolloimaton äänen huojunta voi seurata esittäjän väsymyksestä. Puuskahtavan korostuneen tavun taustalla voi olla muukin kuin surullisuuden tai itkuisuuden kokeminen. Katkonaisen äänen taustalla voi olla naurahtelu. Tällöinkin konteksti ja kulttuurinen ymmärrys ohjaavat tulkintaa. Koska piirteet eroavat itkijöittäin, on tunnetta ja affektiivisuutta arvioitava tapauskohtaisesti. Lisäksi itkuvirren äänitekonteksti, kuten keskustelu ja mahdolliset muut laulut, vaikuttaa tekemiini tulkintoihin, erityisesti itkijän apeutumiseen tai sen välttämiseen viittaavat kommentit ohjaavat tulkintaa. Melko usein itkijä toteaa apeuduttuaan tai ollessaan lähellä apeutumista, ettei halua jatkaa; "en voi enembi/ enämbi" on jopa formulaiseksi tulkittavissa oleva itkun lopetus äänitteillä (104 analysoimastani itkusta 19 loppuu tällaiseen kommenttiin).

Analyysissa lähtötilanteeni kuunteluun on aina jokseenkin vakavamielinen, tietyllä tapaa surullisuuden vastaanottamiseen valmistautunut, mikä vaikuttaa tekemiini tulkintoihin. Yleisesti ottaen kuuntelukokemukseni ei ole kovin affektiivinen eivätkä läheskään kaikki itkut saa aikaan minkäänlaista tuntemusta. Vain jokunen analysoimistani itkuesityksistä herättää selviä tunteita (esim. SKNA 10060:2; SKNA 7592:3/JFS2). Tunteiden sijasta huomaan kuunnellessani ennemminkin jonkinlaista vakavoitumista ja rauhoittumista, toisinaan myös vahvaa empatiaa ja tarvetta olla itkijälle läsnä. Huomaan myös jäljitteleväni tuskaa tai pyrkiväni osallistumaan ja myötäelämään ruumiillani ja ilmeilläni. Nämä ovat erittäin subjektiivisia tapoja reagoida, ja tulkitsen, että niihin vaikuttavat itkuperinteen ja -käytänteiden tuttuus. Jotkin yksittäiset itkut ovat käyneet varsin tutuiksi, mutta näiden ja vähemmän 
tuttujen itkujen kuuntelemisen synnyttämissä kokemuksissa ei ole selvää eroa. Kuuntelemisen intensiteetti tuntuu kohoavan, kun tunteen ilmeneminen muuttuu koetusta kumpuavaksi, olipa se ennen sitä ollut jäljiteltyä tai puuttunut kokonaan. Vastaavanlaisesta kuuntelemisen muuttumisesta kertovat myös vertailuryhmän kuuntelijat.

Äänellä itkemisen tyypillistä äänenväriä voi mielikuvien tasolla kuvailla ontohkoksi, surumieliseksi ja vakavaksi. Se on jollakin tapaa särkyvä, toisinaan jopa rääkyvä, väsynyt ja hento mutta varma ja vakaa ja siten vahva. Kuulostaa, että ääni jää vähän itkijän sisään eikä siis soi kirkkaasti ulospäin. (Ks. SKNA 7592:3/JFS2 äänite-esimerkki²). Sisäänpäin suuntautuvuus tuntuu etäännyttävän kuulijaa luoden itkijälle omaa tilaa. Tulkitsen tämän liittyvän Urbanin hahmottelemaan varsinaisen fyysisen vastaanottajan puuttumiseen, jonka hän näkee yhtenä itkuille tyypillisenä murheen merkkinä $(1988,386)$. Vaikka itkua ei tiettyjä rituaalisia tilanteita lukuun ottamatta osoiteta fyysisesti läsnä oleville kuulijoille, on esitystilanne kulttuurisesti koodattua sosiaalista kommunikaatiota myös näiden kanssa. Sisäänpäin suuntautuvuudesta huolimatta ääni purkautuu toisinaan voimakkaastikin ulos etenkin tunteen yltyessä.

\section{Affektiivisia, tunnetta jäljitteleviä ja tunneilmauksettomia itkuesityksiä}

Analysoimastani aineistosta hahmottuu tunteen ilmenemisen kannalta kolmentyyppisiä itkuvirsiesityksiä: 1) Yhden ryhmän muodostavat arkistoäänitteiden esimerkinomaiset itkuvirsiesitykset, joissa tunne ei tule esiin millään tavalla, mutta tekstin ja sävelmän puolesta nämä voivat olla eheitä esityksiä. Ne on esitetty kuin kertoen "no tällaista se on". (Esim. Fon.1255a/I дор.1; Fon.2781a/1-3, Fon.2781/16-17.) Kaksi muuta ryhmää ovat tunnetta ilmaentäviä itkuesityksiä. 2) tunnetta jäljittelevissä itkuissa tunne on läsnä joko jäljiteltyinä tunteen tunnuksina tai muutoin itkuille tyypillisesti kuten äänenmuodostustapana ja äänenvärinä, mutta itkijä ei havaittavasti apeudu (esim. Fon.2781/16; Fon.3630a/24), kun taas 3) affektiivisissa itkijä on selvästi apeutunut ja tunnetilan vallassa (esim. SKNA 7592:3/ JFS2; Fon.885b/13; Fon.2781/19; Fon.2781/11; Fon.3630b/29). Affektiivisten ja tunnetta jäljittelevien itkuesitysten välisen eron kannalta ratkaisevia tekijöitä ovat itkijän apeutuminen ja tämän välittyminen kuuntelijalle. Eheiden esitysten lisäksi aineistossa on katkelmallisia esityksiä, jotka vaikuttavat esitetyn esimerkkeinä haastattelijan pyytämästä perinteenlajista tai kuin ohimennen malliksi rituaalikuvauksen kerronnan joukossa. Esityksen muoto (eheä/ katkelma) ei ole suoraan yhteydessä esityksen tunteellisuuteen. Vastaavasti se, että itkuvirret on tallennettu haastattelutilanteissa, jotka eivät vastaa ensisijaisia, siltä kannalta autenttisia äänellä itkemisen konteksteja, ei välttämättä suoraan vaikuta siihen, miten tunne itkuvirressä ilmenee (ks. myös Stepanova, E. 2014, 97-98). Sama itkijä voi samassa haastattelutilanteessa esittää itkuja kaikilla hahmottelemillani tunteen ilmenemisen kannalta erilaisilla tavoilla. Itkijä voi esimerkiksi rentoutua haastattelun edetessä, mikä voi tehdä tilanteesta otollisemman apeutumiselle. Toisaalta itkijä voi yhtä hyvin aloittaa affektiivisella esityksellä ja myöhemmin kieltäytyä kokonaan esittämästä tunteellisia itkuvirsiä. (SKNA 7592:3; Fon.1255a/l дор.1; Fon.1255b/Il дор.1; Fon.1256a/5-8.)

Tunneilmaisun kannalta tarkasti analysoimastani 104 itkun aineistosta, jossa lähtökohtaisesti korostuvat täydet esitykset, affektiivisia itkuesityksiä on 44, tunnetta jäljitteleviä 47 ja

2 Äänite-esimerkin mp3 - Tulendavirsi Jeudokia Fedorovna Sofronova 1968 voi ladata omalle koneelleen kuunneltavaksi tämän artikkelin kansisivulta https://doi.org/10.30666/elore.97359. 
tunneilmaisuitta esitettyjä 13. Rajat luokittelujen välillä häilyvät. Tulkinnanvaraisuudesta huolimatta kvantitatiivinen jaottelu antaa selvän suunnan erilaisten itkujen osuudesta aineistokokonaisuudessa, vaikka kuuntelemassani noin viidensadan itkun kokonaisaineistossa tunteetta esitettyjä itkuja on suhteessa enemmän kuin tähän artikkeliin valikoidussa analyysiaineistossa. Ajatus jatkumosta esimerkinomaisesta jokseenkin tunneilmauksettomasta esityksestä riipivän affektiiviseen tunteenpurkaukseen on selvärajaisia luokkia osuvampi. Siitä, mitä kaikkia erilaisia esityskäytäntöjä yhteisössä on rituaalisissa tilanteissa käytetty ja pidetty rituaalisessa mielessä oikeina ja sopivanlaisina, niin sanottuina täysinä esityksinä, ei ole varmuutta. Aiempaan tutkimukseen sekä itkuvirsien kuvauksissa ja haastatteluissa ilmi tulevaan tunteen tarttumiseen perustuen päättelen tunteellisuutta osoittavien piirteiden - jäljiteltynä tai koetusta kumpuavana - olevan täyden ja hyvänä pidetyn esityksen ehto (esim. Kper AK/2940; Konkka 1985, 35; Stepanova, E. 2014, 98-99). Haastattelutilanteissa itkijät kuitenkin toisinaan välttävät apeutumista (esim. SKNA 7592:3).

Tunneilmauksettomat, esimerkinomaiset itkut ovat usein kuin läpi lauletun kuuloisia (esim. Fon.989/4, Fon.991/2, Fon.1255a/l дор.1). Nämä itkuvirret kuvastavat hyvin tekstiä, melodiaa ja rakennetta, mutta tunne-elementit vaikuttavat puuttuvan kokonaan toisinaan genretyypillistä äänenväriä myöten. Tulkintani läpi lauletun kuuloiseksi itkuesitykseksi perustuu analyyttisen kuuntelun lisäksi vertailuun saman itkijäin toisiin itkuesityksiin, jos se on mahdollista. Tapausesimerkkeihin olen valinnut havainnolliset tyyppiesimerkit molemmista tunnetta ilmentävistä, affektiivisista ja tunnetta jäljittelevistä, itkuvirsiesityksistä.

\section{Itkeä vai nauraa? - Tunne jäljitellen esitettynä}

Unelma Konkka tallensi vuonna 1968 tsuralahtelaisen Olga Fedorovna Zaitsevan esittämän hääitkun (Fon.985/4). Itku on kaikkinensa minuutin mittainen, ja siitä hahmottuu kuusi vaihtelevan mittaista musiikillista säettä. Haastattelutilanteessa on mukana kaksi muuta naista, joiden nimet lausutaan äänitteellä osin epäselvästi. Aluksi kaikki kolme esittää yhdessä lauluja, minkä jälkeen äänitteellä on katkos. Äänitys jatkuu kesken eloisan keskustelun häihin liittyvistä lauluista, ja tästä päästään hääitkuihin. Yleisvaikutelma on hälisevä. On vaikea saada selvää, mistä kaikesta puhutaan ja kuka mitäkin sanoo kaikkien ollessa äänessä yhtä aikaa. Yksi alkaa jäljitellä itkemisen ääntä kuin malliksi, mikä aiheuttaa toisissa hymähtelyä. Haastattelutilanteessa esittämiseen saattoi liittyä tällaista huvittunutta tai jonkinlaista epäröivää naureskelua, koska hääitkut olivat pääasiassa jo menneisyyteen jäänyt käytäntö.

Itkuvirsi alkaa suoraan puheen ja hälinän sekaan. Äänitteellä esityksestä erottuu itkijän lisäksi jonkun toisen esitykseen osallistujan ääni. Itkijän ääni ja toisen osallistujan ääni erottuvat toisistaan selvästi. Itkijän tyyli on melodinen (vrt. Silvonen, tulossa), eikä äänirekisterissä, tempossa tai voimakkuudessa kuulu huomiota herättäviä poikkeamia. Molempien osallistujien äänessä kuuluu itkemisen ääniä: itkijällä äänellä itkemiselle tyypillinen äänenväri ja kuuluvia tunteen tunnuksia, ja toisella osallistujalla tavallisen itkemisen äänten jäljittelyä. Itkemisen äänet ja kokonaisilmaisu ovat vuorovaikutuksessa keskenään. Etenkin toisen osallistujan taustalle tuottama ääni tuntuu vaikuttavan itkijän esitykseen. Analyysissä olen tarkastellut osallistujien ääniä erikseen sekä näiden kokonaisuutta. Itkuvirren graafissa (kuva 2) on myös säekaaret, jotka hahmottuvat pääasiassa musiikillisten säkeiden rajoja seuraten (ks. myös Silvonen, tulossa). 
Itkijän äänessä tunteen tunnukset kuten lisääntynyt äänen värinä, korostuneet tavut ja äänen mukana vuotava voimakkaampi uloshengitys kuuluvat fraasien lopuilla eivätkä ne ole erityisen voimakkaita. Selkein tunnus on äänen katkonaisuus, joka kuuluu esityksen alkupuolella hetkellisesti ja palaa itkuvirren lopulla tunneintensiteetin yltyessä. Toisen osallistujan tuottama ääni puolestaan kuuluu nimenomaan tällaisena katkonaisena äänenä, joka muodostaa voimakasalukkeisia, intonaatioltaan laskevalinjaisia kulkuja.

Kuunnellessa oloni on hämmentynyt. Kuuluvasta äänestä on toisinaan vaikea päättää, kuulostaako se hervottomalta naurulta vai hallitsemattomalta itkulta; autoetnografisten havaintojen perusteella äänellisesti nämä ovat varsin lähellä toisiaan ja niihin liittyy samankaltaista fysiologista aktiivisuutta ja kontrolloimattomuutta. Tallenteen kontekstissa olen usean kuuntelukerran jälkeen päätynyt tulkitsemaan kuullun huvittuneisuudeksi ja nauruksi itkemisen jäljittelyn seassa. Itkun edetessä toisen osallistujan ääni muuttuu paikoin varsin hekottavaksi, jopa tikahtuvaksi. Pelkkää itkijän ääntä kuunnellen kontekstistaan irrallisena kyseessä voisi olla myös itkeminen. Kokonaisuus kuitenkin tukee tulkintaani tunteen yltymisestä nauramiseksi. Etenkin esityksen lopulla nauru valtaa alaa molempien ilmaisussa, ja heti itkun loputtua ilmeisesti toinen osallistuja päivitteleekin naurahtaen "voi mikä...", josta jatkuu vilkas rupattelu. Esityksen keskivaiheilla taustalla kuuluu myös muiden läsnäolijoiden naurahtelua ja hihitystä.

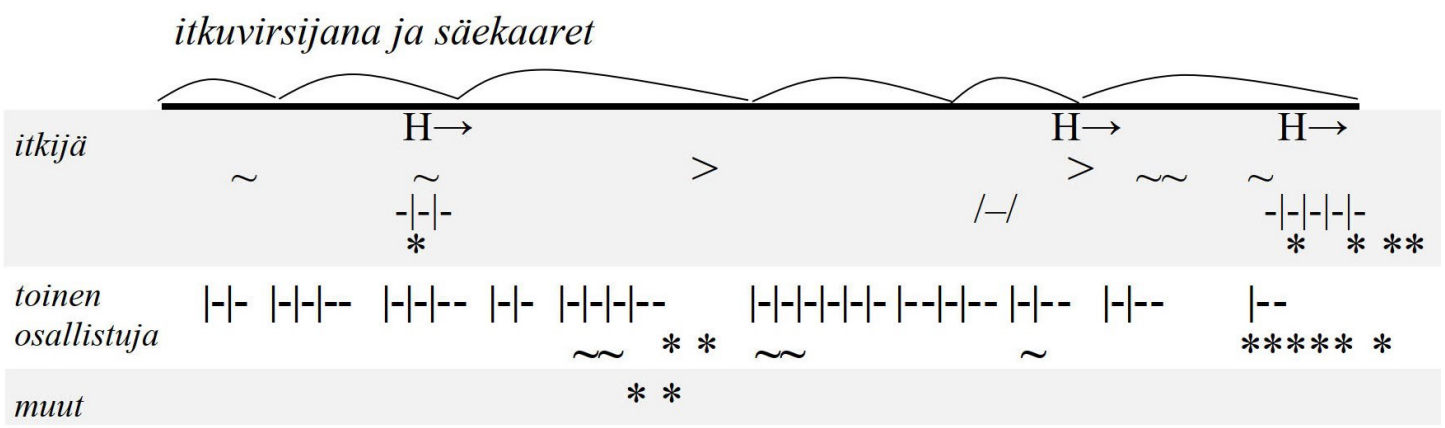

Merkinnätjanalla

kaaret janan yläpuolella kuvaavat itkun säkeitä

$\mathrm{H} \rightarrow$ voimakas uloshengitys, äänteen yhteydessä ilmaa ulos

$>\quad$ korostunut, puuskahtavasti lausuttu äänne (edeltävää voimakkaampi)

/-/ kireä, jännitteinen, tukahtuva ääni, puristunut

epävakaa ääni, huojunta

---- katkonainen ääni

* nauruksi tulkittavat äänet

Kuva 2. Tunnepiirteiden kuulumisen graafinen esitys hääitkusta (Fon.985/4).

Tässä itkussa tunne kuuluu vahvasti, mutta itkun äänet ovat selvästi tarkoituksellisesti tuotettuja. Kokonaisuus vaikuttaa näytellyltä - koettua apeutta ei ole mukana. Ensikuunteluni (syksy 2018) kommenttina apeudesta olen kirjannut "on, performatiivista". Tunteen ilmeneminen ei siis ole vaikuttanut lainkaan koetusta kumpuavalta. Analyyttisempien kuuntelun jälkeen (kevät 2020) tulkinta on jokseenkin sama, mutta mieleni on epävarma, koska esityksen tunneintensiteetti kohoaa selvästi, mutta on vaikea tietää, onko äänitteellä kuulemani itkua, naurua, tekoitkua, tekonaurua vai mitä. Mitä useamman kerran kuuntelen äänitettä, sitä enemmän kuunteleminen naurattaa. Välittyvä tunnelma on iloisen vapautunut eli aivan toisenlainen kuin affektiivisen itkuvirsiesityksen jälkeen. Itkuvirsigenreen kuuluva surumielisyys ja apeus ovat poissa. 
Useiden kuuntelu- ja tulkintakierroksen jälkeen olen päätynyt tulkitsemaan arkistoäänitteen itkuvirren esityksenä jotakuinkin täydelliseksi tunnetta jäljitteleväksi hääitkuperformanssiksi. Itkijän lisäksi näytellyssä performanssissa on mukaan morsian eli antilas, joka rituaalista käytäntöä noudattaen itkee silmin samaan aikaan kun itkijä eli olallinen äänellä itkee. Esitys täyttää kaikki täyden esityksen piirteet, kielen, sävelmän, äänenmuodostuksen ja kuuluvan tunteen sekä hääitkulle erityisenä silmin itkevän antilaan ja hänen puolestaan äänellä itkevän olallisen.

\section{Apeus hiipii kuin salavihkaa}

Riipuškalasta kotoisin oleva Jeudokia Fedorovna Sofronova esitti affektiivisen kuolinitkun, tulendavirren, etnografisessa haastattelussa vuonna 1968 (SKNA 7592:3/JFS2, myös äänitteenä). Tulendavirsi on rituaalinen itkuvirsi, jolla kutsutaan vainajan kauempana asuvia sukulaisia hautajaisiin. Sofronova kertoo laatineensa tämän itkun sisarensa kuoltua. Itkuvirsiesitys on noin kahdeksan minuutin mittainen, musiikillisia säkeitä hahmottuu 42. Myös muunlaiset säetulkinnat ovat mahdollisia vapaamittaisesta rakenteesta, itkun improvisatorisesta luonteesta sekä musiikin ja tekstin yksiköiden paikoittaisesta epäyhtenäisyydestä johtuen. (Silvonen, tulossa.) Haastattelussa itku on yhteensä seitsemästä äänellä itketystä toinen. Äänitteen aluksi tallentaja Pertti Virtaranta kertoo olevansa Eino Kiurun kanssa itkijän luona ja listaa itkijän henkilötiedot. He keskustelevat itkijän elämän vaiheista, ja Virtaranta pyytää Sofronovaa sanelemaan itkun. Pyyntöä seuraa muutaman minuutin suostuttelukieltäytymis-keskustelu. Lopulta itkijä suostuu äänellä itkemään itkun lapsivainajalle, josta siirtyy melko suoraan tulendavirteen. Itku lapsivanajalle on genretyypillisesti tunnetta ilmentävä, mutta affektiivisuuteen viittaavia piirteitä on niukasti jos lainkaan; kuullun perusteella itkijän lähtötunnelma tulendavirteen vaikuttaa tunteellisesti melko neutraalilta.

Tulendavirrestä hahmottuu neljä temaattista osiota. Ensimmäinen on rituaalinen jakso, joka keskittyy kontekstisidonnaisiin teemoihin eli kertoo kuolemasta. Tätä seuraa pyyntöosio, jossa itkijä pyytää vainajaa viemään viestiä tuonilmaiseen aiemmin kuolleille omaisilleen. Kolmas ja neljäs osio muodostavat omaelämäkerrallisen osion: kolmas käsittelee itkijän aviomiehen kuolemaa ja siitä seuranneita suruja ja kärsimyksiä, neljäs itkijän pojan kuoleman aiheuttamaa tuskaa ja onnettomuutta (temaattiset jaksot merkitty analyysigrafiikkaan, kuva 3). Esityksen tunneintensiteetti yltyy omaelämäkerrallisiin jaksoihin tultaessa, ja itkijä apeutuu voimakkaasti loppua kohden. Itkijän tyyli on varsin melodinen ja linjakas, ääni on

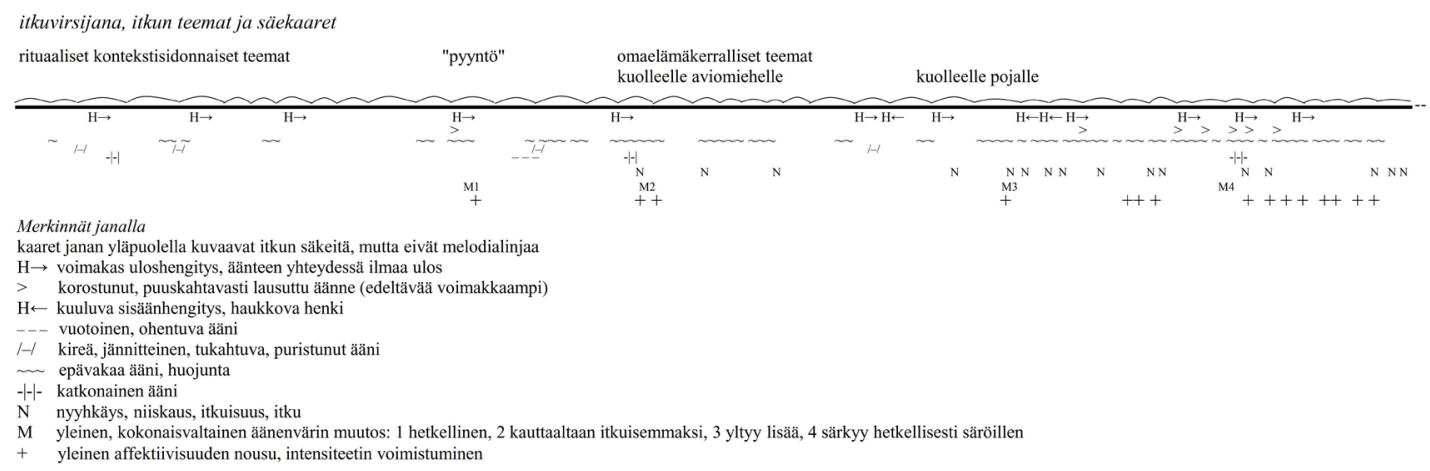

Kuva 3. Graafinen kuvaus tulendavirrestä (SKNA 7592:3/JFS2, myös äänitteenä). Jokaista tunnusta ei ole merkitty luettavuuden säilymiseksi. 
varma ja vakaa kauttaaltaan. Sofronova ei käytä falsettia, tempo ja äänenvoimakkuuskin ovat varsin tasaiset.

Itkuvirren alusta saakka äänenväri on äänellä itkemiselle tyypillinen esityksellisesti vahva, mutta hentoinen. Ääni ei tunnu aktiivisesti luovan yhteyttä muihin läsnäolijoihin. Äänessä on äänellä itkemiselle ominaista huojuntaa ja puristuneisuutta sekä jonkinlaista särkyneisyyttä, jotka ohjaavat yleisellä tasolla esityksen tunnistamista itkuvirreksi. Melko alusta saakka kuuluu myös toisinaan äänteiden mukana vuotava uloshengitysilma, mikä luo kokonaisuuteen huokaavuutta ja jollakin tapaa etäännyttää esittäjää omaan tilaansa sekä toisaalta luo kuuntelialle mielleyhtymän haikeamielisyydestä. Nämä piirteet liittyvät kulttuurisiin konventioihin itkuvirsien esittämisestä.

Ensimmäiset selvät tunteen tunnukset tulevat rituaalisen osion lopulla lisääntyvänä äänen värinänä kohdassa, jossa tekstissä kuvataan vainajan peittelemistä maahan "tuorehien turbehusien alle". Samanlaista kuuluvaa soinnin ja säveltasojen pientä epävakautta ja äänenvärin hetkellisiä muutoksia on heti seuraavana tulevan pyyntöosion alussa mutta vain hetkellisesti, yleisilmaisu jatkuu tasaisehkona. Ensikuunteluilla nämä tuntuivat jäljitellyiltä, osittain sen takia, että ne ovat melko yksittäisiä ja vaikuttivat täysin kontrolloiduilta eikä tunnetila välity selvästi. Myös useampi vertailukuuntelija kommentoi näiden kuulostavan jäljitellyiltä. Tarkemman auditiivisen analyysin ja oman kuuntelukokemuksen tarkkailun perusteella tulkitsen nämä kuitenkin jonkinasteisesti koetusta kumpuavaksi ilmenemiksi. Tulkintaani tukee se, että hengityksessä alkaa kuulua hiljalleen enemmän viitteitä apeutumisesta. Tällaisia viitteitä ovat hengästyminen ja kontrolloimattomilta kuulostavat voimakkaat uloshengitykset, myös joidenkin tavujen lausuminen korostuu. Tässä itkussa kokemuspohjainen ja jäljitelty tunteen ilmeneminen limittyvät. Samalla tavalla selvästi erottumattomina ne ilmenevät useimmissa affektiivisissa itkuissa.

Pyyntöosion alussa tulee ensimmäinen voimakas puuskahtava tavu, jota seuraavassa fraasissa äänenväri muuttuu kokonaisvaltaisesti hetkeksi - ikään kuin itkijä pidättelisi kyyneliään (kaaviossa M1). Pyyntöosion tunnetila kuulostaa pysyvän melko tasaisena mutta on jo alkua affektiivisempi. Tunnetta ilmentäviä äänenpiirteitä kuuluu taajemmin, ja tulkitsen ne ennemmin koetusta kumpuaviksi kuin jäljitellyiksi. Tulkintani perustuu osin itkijän henkilökohtaisen tyyliin. Arkistoäänitteiden perusteella Sofronova käyttää suhteellisen vähän jäljiteltyjä tunteen tunnuksia, ja hänen tyylissään tunnetta ilmentävät muut esityksen piirteet, erityisesti itkuvirsille ominainen äänenväri.

Itkuesityksen affektiivinen intensiteetti kohoaa vähä vähältä, ja itkuvirsi vetää minut kuuntelemaan tiiviimmin. Tunne alkaa ilmetä enenevissä määrin myös säkeiden kesken, kun taas itkun alkupuolella tunteen tunnukset ovat melko järjestään säkeiden lopulla (ks. myös Silvonen, tulossa; vrt. Rüütel ja Remmel 1980, 179). Varsinaisia niiskauksia alkaa kuulua kerronnan vaihtuessa aviomiestä muistelevaan osioon. Yleisäänenväriin tulee itkuisuutta, joka kuuluu kevyenä nasaalisuutena (M2); tunne alkaa vaikuttaa suoraan äänenmuodostumiseen. Ääni käy entistä värisevämmäksi ja hengitys paikoin raskaammaksi. Apeus ryöpsähtelee pintaan siellä täällä yksittäisinä niiskauksina ja voimakkaina henkäyksinä. Tällaisten ryöpsähdysten määrä tihenee itkijän päästessä poikansa kuolemaan ja siitä aiheutuneisiin murheisiin liittyviin teemoihin. Äänenväri muuttuu taas kokonaisuudessaan entistä itkuisemmaksi (M3), ja itkuvirttä alkaa hallita silmin itkemisen ääni. Kokonaisuus muuttuu kuin kyynelten läpi tulevaksi. Kohti itkuvirren loppua niiskauksia alkaa olla paljon, hengitys on kauttaaltaan 
puuskahtelevaa ja haukkovaa, korostuneita tavuja on taajaan. Itkijän ääni särkyy tunteen vallassa hetkellisesti särölle (M4). Itkuvirsi loppuu niiskauksiin ja syviin huokauksiin. Itkijä alkaa palailla esityksen luomasta omasta tilastaan haastattelutilanteeseen. Haastattelijat ovat vielä hetken hiljaa antaen itkijälle tilaa toipua apeudesta. Kokonaisuudesta välittyy vakava mutta rauhallinen tunnelma. Jeudokia Fedorovna Sofronovan esittämässä tulendavirressä affektiivisuutta on niin itkijän ja itkun välillä - itkijän tunnetila yltyy yltymistään itkuvirren edetessä - kuin arkistoääniteeltä kuuluvan itkuesityksen ja sen kuuntelijan välillä.

\section{Affektiiviset kehät}

Itkuvirsien affektiivinen vuorovaikutus on moninaista. Tutkimuksessani hahmotan näitä affektiivisuuden vaihtelevia ilmiöitä ja vaikutusaloja affektiivisen kehän käsitteellä. Esitystilanteessa affektiivisia kehiä muodostuu itkijän ja itkuvirsiesityksen, itkijän ja kuulijoiden sekä esityksen ja kuulijoiden välille. Itkuvirsistä ja itkuvirsiesityksistä kielenulkoisella tasolla nouseva affektiivinen teho on moniulotteinen ilmiö, joka perustuu toisiinsa punoutuviin kulttuuris-sosiaalisiin, psykologisiin ja fysiologisiin tekijöihin.

Itkuvirsien esittämistilanteessa syntyy useita päällekkäisiä affektiivisia kehiä. Itkijän ja itkuvirren (itkuvirsiesityksen) välille äänellä itkettäessä muodostuva affektiivinen kehä on tunnetta yllyttävä, suggestiivinen kehä, jossa esittäminen kokonaisuudessaan vaikuttaa affektiivisesti itkijään ja tämän tunnekokemus edelleen ilmaisuun (vrt. Siikala 1978, 332). Äänellä itkiessään itkijä on perinteisten myyttisten käsitysten mukaisesti yhteydessä tuonpuoleiseen, muistelee ja kertaa kokemuksiaan tuonpuoleisessa kuuleville, esimerkiksi äidilleen, ja myyttinen tausta ja omakohtaiset muistot herättävät tunteita. (Ks. myös Silvonen ja Stepanova 2020.) Näin äänellä itkeminen muodostaa affektiivisen kehän myös itkijän ja hänen hahmottamansa, kulttuurisissa käsityksissä läsnä olevan tuonpuoleisen välille. Itkijän ja itkuvirren kautta tuonpuoleinen on läsnä myös koko yhteisössä. Kun äänellä itkettäessä on läsnä muita inmisiä, tavoittaa itkuvirren ilmaisu kuulijat, ja niin esityksen ja kuulijoiden kuin itkijän ja kuulijoiden välille voi syntyä affektiivinen kehä. Näiden risteävien, toisiinsa limittyvien kehien lisäksi esitystilanteen kokonaisuuden voi hahmottaa laajempana affektiivisena kehänä. Affektiivinen intensiteetti voi tavoittaa kuulijoita myös arkistoäänitteen välityksellä. Vaikka arkistoäänitteen itkuesityksen ja äänitteen kuuntelijan välille ei synny varsinaista vuorovaikutteista affektiivista kehää, voi tämänkin suhteen hahmottaa affektiivisena kehänä tai

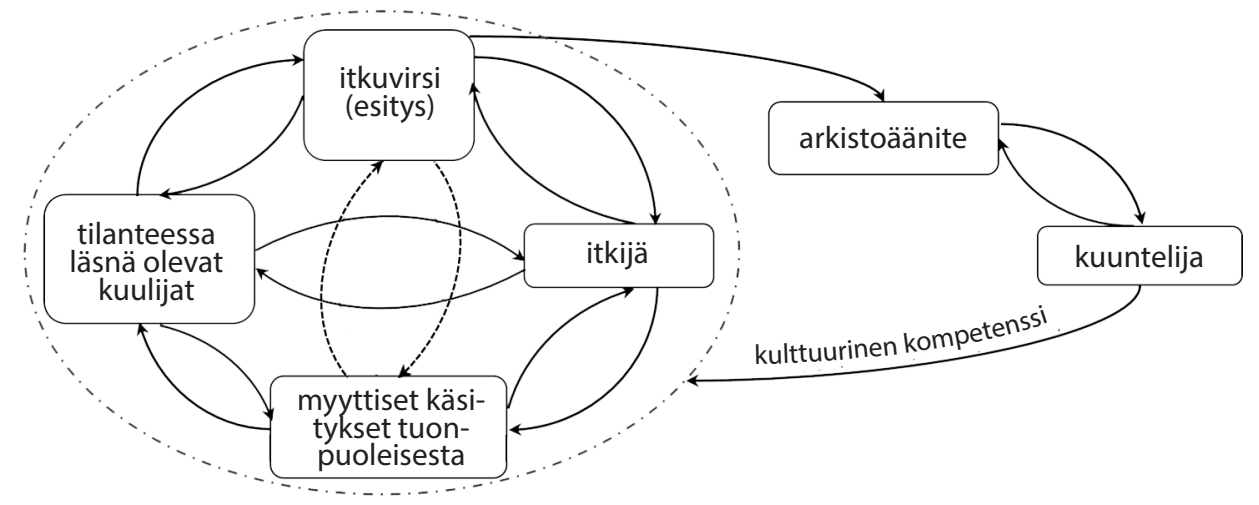

Kuva 4. Affektiiviset kehät kuvaavat itkuvirren affektiivisia ilmiöitä ja vaikutusaloja. Nuolet kuvaavat moninaisia vuorovaikutteisia suhteita, kuten affektiivisuutta, merkityksen antoa sekä monimuotoista kommunikaatiota ja/tai tulkitsemista. Näistä suhteista muodostuu affektiivisia kehiä. Katkoviivakehä kuvastaa esitystilanteen kokonaisuuden affektiivista kehää. 
sen puolikkaana. Kuuntelijan tekemät tulkinnat arkistoäänitteeltä välittyvästä itkuvirrestä vaikuttavat äänitteellä jäljempänä kuuluvasta tehtäviin tulkintoihin. (Kuva 4.)

Vertailukuuntelijoiden haastattelujen ja analyysini perusteella apeus välittyy sellaisista arkistoäänitteiden itkuvirsiesityksistä, joissa itkijä selvästi apeutuu eli muutos jäljitellen esitystä ilmaisusta kokemuspohjaiseen tunteen ilmenemiseen kuuluu. Sen sijaan yksittäiset jäljitellyt tunteen tunnukset tulkitaan melko yksiselitteisesti teennäisiksi ja jäljittelemiseksi tai niitä ei osata tulkita ollenkaan sopivan tulkintamallin puuttuessa. Myös tulkitsemisen vaikeus ja epämääräisyys tulee ilmi. Eräs kuuntelija kuvailee esittäjän kuin hymähtelevän niin, ettei voi tietää onko kyse huvittuneisuudesta vai oikeasta surullisuudesta. Lähes kaikki kommentoivat havainneensa muutosta tunteikkuuden ilmenemisessä kuullussa itkuvirressä, kun kuunneltu itku oli affektiivisten itkuvirsiesitysten ryhmästä. Lisäksi vertailuaineistosta käy ilmi affektiivisen itkuvirren kuuntelemisen immersiivisyys eli mukaansa tempaava upottavuus.

Itkuvirren affektiivisuus voi siis osin välittyä, vaikka itse traditio olisi vieras ja tekstistä ei ymmärtäisi mitään. Jotta itkuvirsi voi vaikuttaa affektiivisesti, on esityksessä oltava jotakin tunnistettavaa ja tuttua (ks. myös Ben-Ze'ev 2010, 3-5, 10-13; Wetherell 2012, 78). Tuttuus ei ole yksiselitteistä ja ilmeistä, vaan myös näennäisesti vieras voi olla affektiivista. "Kun ei ymmärtänyt sanoja, niin ryhtyy empatiseeraamaan ääntä", kuten yksi kuuntelijoista totesi. Tällainen affektiivisuus liittyy tunteiden sosiaalisuuteen, joka on kulttuuris-sosiaalisten seikkojen lisäksi yhteydessä tunteiden tunnistamisen ja välittymisen neuropsykologisiin prosesseihin.

Itkuvirren affektiivisuuden välittyminen ei vaikuta tarvitsevan erityistä kulttuurista tietoa, kun itkuvirressä ilmenevä, kuuluva tunne perustuu koettuun tunnetilaan. Mitä enemmän itkuvirsiesityksessä kuuluva tunne perustuu tunteen tunnusten jäljittelyyn, sitä keskeisemmäksi kuuntelijan kulttuurinen kompetenssi käy kokonaisuuden ymmärtämisen ja affektiivisen tehon kannalta. Itkuvirren varsinaiset merkitykset avautuvat vain kulttuurisesti kompetenteille kuulijoille. Affektiivisten kehien lisäksi itkuvirret muodostavat siis merkitysten kehiä, joihin kuuluvat kulttuurin jollakin tapaa tuntevat.

Myös artikkelini alun Elias Lönnrotin ja Volmari Porkan sitaateista voi hahmottaa affektiivisia kehiä. Lönnrot kuvailee sanomalehti Mehiläisen lukijakunnalle vuonna 1836 ilmestyneessä matkakertomuksessaan erikoista kokemustaan hieman kummeksuvaan sävyyn. Tekstistä käy selväksi se, että itkuesitys on ollut affektiivinen ja myös Lönnrot on sen tehon kokenut. Porkan Valvoja-lehdessä julkaistu teksti on sävyltään neutraalimpi, eikä siitä välity omakohtaista kokemusta. Sen sijaan hän kirjoittaa suoraan, miten itkijän esitys lumoaa läsnäolijat $(1883,200)$, eli kuvaa itkijän esityksen ja kuulijoiden välille muodostuvan affektiivisen kehän.

\section{Lopuksi}

Apeutuminen eli itkijän tunnetilan ja -intensiteetin syveneminen on itkuvirsien keskeinen ominaispiirre, jonka myös itkijät itse tunnistavat ja nimeävät. Tässä artikkelissa olen syventynyt apeuden moninaiseen ilmenemiseen aunuksenkarjalaisten itkuvirsien arkistoäänitteillä. Olen selvittänyt, mitä tunteet ovat tässä aineistossa ja miten ne ilmenevät, sekä tarkkaillut itkijän apeutumisen välittymistä arkistoäänitteeltä kuuntelijoille. Tutkimustulokseni ovat linjassa aiempien myös tunteita huomioivien itkuvirsitutkimusten kanssa, mutta syventää ja monipuolistaa aiemmin esitettyä. Aiemmin itkujen tunteet eivät ole olleet tutkimuksen 
keskiössä. (Urban 1988; Tolbert 1988; 1990; myös Stepanova, E. 2014, 94-95, 98-100.) Tutkimusasetelmaani liittyy myös kysymys siitä, miten menneisyyden tunnekokemusta voi tulkita ja analysoida arkistoäänitteeltä. Koska tunteiden ilmaisu ja välittyminen ovat monikanavaisia prosesseja, analyysi on mahdollista vain tietyillä tasoilla, kun arkistoäänitteillä osa tunnekokonaisuudesta jää väistämättä tavoittamattomiin.

Arkistoäänitteillä kuuluvien menneisyyden tunteiden jäljille olen päässyt soveltamalla useita menetelmiä. Työn taustana ovat itkuvirsitutkijana kerryttämäni kulttuurinen kompetenssi, laaja teoreettinen ymmärrys ja ennen kaikkea usean vuoden ajalle ulottuvan monitahoisen analyyttisen kuuntelemisen tuottama aineiston tuntemus. Analyysissani aistietnografinen havainnointi, empaattinen kuuntelu ja tunneteoreettinen ymmärrys tuovat syväulotteisuutta auditiiviseen äänen analyysiin sekä auttavat havaitsemaan ja tulkitsemaan arkistoäänitteillä kuuluvia viitteitä tunteesta. Aiempaan tutkimukseen sekä arkistoäänitteisiin perustuva tieto ja ymmärrys itkuvirsistä rituaalisena kulttuurisena käytäntönä taas mahdollistavat perusteltujen tulkintojen tekemien näistä kuunteluanalyysissa esiin nousevista tekijöistä.

Arkistojen itkuvirsiaineistosta hahmottuu apeuden ilmenemisen kannalta kolmenlaisia itkuvirsiesityksiä: affektiivisia eli apeutuvia, tunnetta jäljitteleviä ja tunneilmauksettomia. Itkuvirsiaineistojen ja aiemman tutkimuksen perusteella oletan, että tunneilmauksettomat esitykset ovat lähtökohtaisesti haastattelukonteksteissa muotoutunut esitystapa, ja tunnetta ilmentävät eli affektiiviset ja tunnetta jäljittelevät itkuvirsiesitykset ovat olleet varsinaisia tapoja esittää itkuvirsiä. Kuitenkaan siitä, minkä kaiken laiset esitystavat ovat olleet itkijöiden käytössä yhteisössään, ei ole varmaa tietoa. Analyysini osoittaa, että itkuvirsissä tunne on mukana itkijän kokemuksena ja itkijän esittämänä. Apeus ilmenee sekä genretyypillisin keinoin jäljiteltynä että itkijän henkilökohtaisesta hetkellisestä kokemuksesta kumpuavana. Jäljitelty tunteen ilmeneminen ei ole vain tarkoituksellisesta tunteen tunnusten esittämistä, vaan osana itkuvirsiperinnettä omaksuttu, mahdollisesti automatisoitunut kulttuurinen käytäntö. Äänellä itkemisessä nämä ilmenemismuodot, jäljitellyt ja koetusta kumpuavat tunteen tunnukset, limittyvät, ja näyttää ilmeiseltä, että molemmat ovat olleet itkukulttuurissa yhtä lailla käypiä, genren mukaisia täyden itkuesityksen merkkejä. Itkijän apeutuminen tulee ilmi kontrollin heikkenemisenä. Auditiivisen analyysin ja empaattisen kuuntelun yhdistävän analyysini mukaan apeutumiseen viittaava ilmaisun kontrolloimattomuus kuuluu muutoksina äänenvärissä ja -käytössä, hengityksen haukkomisena, korostuneina uloshenkäyksinä ja niiskutuksena sekä esityksen intensiteetin kohoamisena. Varsinaista itkemistä, jonka voi tunnistaa äänitteeltä äänen vetisyytenä ja limaisuutena, pidän selvimpänä yksittäisenä merkkinä itkijän apeutumisesta. Apeuden yltyessä tällaiset niin sanotut nyyhkytykset sijoittuvat pitkin fraasia, kun taas itkemistä jäljiteltäessä nyyhkytys asettuu usein fraasien väliin, ja aiemmassa tutkimuksessa puhutaankin toisinaan nyyhkytysjaksoista. Mikään yksittäinen piirre ei kuitenkaan sellaisenaan osoita apeutumista ja affektiivisuutta, vaan keskeistä ovat affektiivisuuden ilmenemiseen vaikuttavien tekijöiden kontekstiin sidoksissa olevat yhdistelmät. Äänellä itkettäessä tunneintensiteetin nousu eli apeutuminen on monisyinen ilmiö, johon vaikuttavat itkuvirsien genretyypillisten tunteen tunnusten jäljitteleminen, itse itkuvirsi teksteineen ja sävelmineen sekä sosiaaliset, kulttuuriset, kontekstuaaliset ja henkilökohtaiset tekijät (ks. myös Silvonen ja Stepanova 2020). Analyysini mukaan se, että kuuntelija havaitsee jollakin tasolla jäljitellyn ja koetusta kumpuavan tunteen ilmenemisen välisen eron ja erityisesti muutoksen jäljitellystä kokemuspohjaiseen, on affektiivisuuden ja itkijän apeutumisen välittymisen kannalta olennaista. Itkuvirren ja äänellä itkemisen synnyttämiä erilaisia affektiivisuuden välittymisen ja apeuden yltymisen ilmiöitä sekä affektiivisia 
vaikutusaloja kuvaan affektiivisen kehän käsitteellä. Affektiivisia kehiä syntyy itkijän, itkuvirren, läsnä olevien kuulijoiden ja perinteisten myyttisten käsitysten mukaisen tuonpuoleisen kesken. Nämä risteävät kehät muodostavat yhdessä laajemman affektiivisten suhteiden kehän. Analyysini osoittaa, että myös arkistoäänitteen itkuvirren ja kuuntelijan välille voi syntyä eräänlainen affektiivinen kehä.

Tutkimukseni on ensimmäinen itkuvirsien apeuden kirjoa ja affektiivisuuta analysoiva tutkimus ja tuo folkloristisen tutkimuksen kentälle uusia tapoja ja keinoja ymmärtää tunteita ja ilmaisua eri aloja yhdistävin näkökulmin ja menetelmin. Koska tunteet ovat erottamaton osa kaikkea inhimillistä kommunikaatiota, tämän artikkelin menetelmät ja näkemykset ovat sovellettavissa itkuvirsitutkimusta laajempaankin keskusteluun. Kaikkiaan esityskokonaisuuteen, esittämistapoihin ja kuunteluun perustuva tutkimukseni luo uudenlaisia tapoja lähestyä ja käsitteellistää itkuvirsiä perinteenlajina. Äänellä itkemisen tunneilmaisua ja -kokemusta korostava näkökulmani myötä itkuvirsien kirjo sekä menneisyyden itkuvirsiperinne ja nykyajan itkuvirret on mahdollista asettaa mielekkäästi samalle jatkumolle erilaisista kulttuurisista ja sosiaalisista konteksteista huolimatta: Kun itkuvirsiä hahmottaa rituaalisten käytäntöjen sijasta yleisemmän tason yhteisöllisten merkitysten, yksilön kokemuksen ja ilmaisun näkökulmin, voi etnografisissa haastatteluissa tallennetut itkut hahmottaa helpommin rituaalisten tilanteiden äänellä itkemisen rinnalle. Samoin perustein on itkuvirsiperinteen modernissa yhteiskunnassa saamia muotoja mahdollista tarkastella entistä monipuolisemmin menneisyyden itkuvirsiperinteen jatkajana.

Itkijän apeutuminen - tunteen nouseminen pintaan ja äänellä itkemisen intensiteetin kohomaminen - on kenties itkuvirsien vaikuttavin piirre, ja sen affektiivinen teho voi ulottua omaa kulttuurista piiriaän laajemmalle. Äänellä itkemisen kuuleminen käwi jo Lönnrotin karwoille, wihlasi läpi ruumiin ja jäsenten (Lönnrot 1836), ja se vakavoittaa kuuntelijat myös nykyaikana.

\section{Tutkimusaineistot}

Fon. $=$ Venäjän tiedeakatemian Karjalan tutkimuskeskuksen Kielen, kirjallisuuden ja historian instituutin arkisto (IJALI, ИЯЛИ КарНЦ РАН). Petroskoi.

Kper $=$ Kansanperinteen arkisto, Yhteiskunta- ja kulttuuritieteiden yksikkö, Tampereen yliopisto.

SKNA = Suomen kielen nauhoitearkisto. Kotimaisten kielten keskus. Helsinki.

SKS KRA = Suomalaisen Kirjallisuuden Seuran arkisto, perinteen ja nykykulttuurin kokoelma. Helsinki.

Fon.144/2. О.Т.Кюччиева (О. T. Kjutšieva).1961. Nauhoittaja: Г.Н.Макаров (G. N. Makarov).

Fon.885b/13. А.И.Никитина (А. І. Nikitina). 1967. Nauhoittajat: T.A.Коски (Terttu Koski), А.А.Митрофанова (А. А. Mitrofanova).

Fon.985/4. О.Ф.Зайцева (Olga Fedorovna Zaitseva), Jeudokia Konanovna Poromkina ja Anastasia Vasiljevna [sukunimi]. 1968. Nauhoittajat: У.С.Конкка (Unelma Konkka), П.И.Лукина (Р. I. Lukina), Н.Ф.Онегина (N. F. Onegina).

Fon.989/4. А.Н.Ипатова (А. N. Ipatova). 1968. Nauhoittajat: ks. Fon.985/4.

Fon.991/2. Ф.Жидкова (Fekla Mihailovna Shidkova). 1968. Nauhoittajat: ks. Fon.985/4. 
Fon.1255a/I дор.1. А.В.Чеснокова (Anna Vasiljevna Tšesnakova). 1968. Nauhoittaja: В.Д.Рягоев (V. D. Rjagojev).

Fon.1255b/ll дор.1. ks. Fon.1255a/l дор.1.

Fon.1256a/5-8. ks. Fon.1255a/l дор.1.

Fon.2781/11. Е.Ф.Анхимова (E. F. Anhimova). 1983. Nauhoittajat: Pekka Laaksonen, Eino Kiuru, T.В.Лукина (T. V. Lukina).

Fon.2781a/1-3. Е.Ф.Софронова (Jeudokia Fedorovna Sofronova). 1983. Nauhoittajat: ks. Fon.2781/11.

Fon.2781/16-19. ks. Fon.2781a/1-3

Fon.3630a/24.А.Ф.Семукова (A. F.Semukova). 2001.Nauhoittaja:A.С.Степанова (Aleksandra Stepanova), М.А.Михайлова (М. A. Mihailova).

Fon.3630b/29. ks. Fon.3630a/24.

Kper AK/2940. Anastasia (Nasti) Ronkainen. 1973. Nauhoittaja: Erkki Ala-Könni.

SKNA 7592:3/JFS1-5³. Jeudokia Fedorovna Sofronova. 1968. Nauhoittaja: Pertti Virtaranta ja tutkimusryhmä. ${ }^{4}$

SKNA 7593:1. ks. SKNA 7592:3.

SKNA 10060:2. Stepanida Fedorovna Grigorjeva. 1972. Nauhoittaja: ks. SKNA 7592:3.

SKNA 10114:2. ks. SKNA 10060:2.

SKS KRA A 886/20. Tatjana Hötti. 1962. Nauhoittaja: Anna Romonen.

SKS KRA A 375/5. Irinja Reijonen. 1958. Nauhoittaja: Lauri Simonsuuri ja Leena Pälikkö.

Vertailuryhmän haastattelut, 5 haastateltavaa. Haastattelija: Viliina Silvonen. Haastatteluita ei äänitetty eikä niistä ole tarkkoja litteraatioita. Haastattelumuistio, Liite 1.

\section{Kirjallisuus}

Anttonen, Salli. 2019. "Sunrise Avenue ja aitouden kaipuu. Autenttisuuden diskurssit populaarimusiikissa." Etnomusikologian Vuosikirja 31. 63-88. https://doi.org/10.23985/ evk.81271

Bauman, Richard. 1984. Verbal Art as Performance. Prospect Heights, Ill.: Waveland Press.

Barrett, Lisa Feldman. 2017. "The theory of constructed emotion: an active inference account of interoception and categorization." Social Cognitive and Affective Neuroscience 12(1). 1-23, https://doi.org/10.1093/scan/nsw154

Ben-Ze'ev, Aaron. 2010. "The Thing Called Emotion." Teoksessa The Oxford Handbook of Philosophy of Emotion, toimittanut Peter Goldie, 1-23. Oxford handbooks in philosophy. Oxford: Oxford University Press. https://doi.org/10.1093/ oxfordhb/9780199235018.003.0003

Briggs, Charles. 1992. "'Since I Am a Woman, I Will Chastise My Relatives': Gender, Reported Speech, and the (Re)production of Social Relations in Warao Ritual Wailing." American Ethnologist 19.337-361. https://doi.org/10.1525/ae.1992.19.2.02a00080

3 Suomen kielen nauhoitearkiston äänitteitä ei ole eritelty sisällysnumeroin, joten olen tehnyt äänellä itketyille itkuille koodit itkijän nimikirjaimista ja itkun numerosta, kun samalla äänitteellä on useita itkuja.

4 JFS2 myös äänitteenä ladattavissa omalle koneelle kuunneltavaksi tämän artikkelin kansisivulta https://doi. org/10.30666/elore.97359 
Daly, Anya. 2016. Merleau-Ponty and the Ethics of Intersubjectivity. Lontoo: Palgrave Macmillan. https://doi.org/10.1057/978-1-137-52744-8

Drollinger, Tanya, Lucette, B. Comer ja Patricia T. Warrington. 2006. “Development and Validation of the Active Empathetic Listening Scale." Psychology \& Marketing 23(2): $161-$ 180. https://doi.org/10.1002/mar.20105

Feld, Steven. 1990. "Wept Thoughts: The Voicing of Kaluli Memories." Oral Tradition 5(2-3): 241-266.

Foley, John Miles. 1995. The Singer of Tales in Performance. Bloomington: Indiana University Press.

Gomon, Alla 1976. "O muzïkal'nïkh osobennostyakh karel'skik prichitaniy." Teoksessa Karel'skiye prichitaniya, toimittaneet Aleksandra Stepanova ja Terttu Koski, 441-487. Petroskoi: Karelija.

Hakamies, Pekka. 1993. Venäjän-Taipaleelta Viinijärvelle. Erään karjalaisryhmän identiteetistä ja assimilaatiosta. Helsinki: Suomalaisen Kirjallisuuden Seura.

Hakamies, Pekka. 1995. "Runotraditiot ja etnis-uskonnollinen raja llomantsissa." Teoksessa Runojen Ranta. Mekrijärven Sissola, toimittaneet Jorma Aho ja Laura Jetsu. 182-189. Helsinki: Suomalaisen Kirjallisuuden Seura.

Heinonen, Kati. 2008. "Tunne arkistonauhalla: äänensävyjä ja aukkoja." Teoksessa Ääniä arkistosta, toimittaneet Outi Fingerroos ja Tuulikki Kurki, 234-260. Helsinki: Suomalaisen Kirjallisuuden Seura.

Honko, Lauri. 1963. "Itkuvirsirunous." Teoksessa Suomen Kirjallisuus I: Kirjoittamaton Kirjallisuus, toimittanut Matti Kuusi, 81-128. Helsinki: Suomalaisen Kirjallisuuden Seura.

Hymes, Dell. 1975. "Breakthrough into Performance." Teoksessa Folklore: Performance and Communication, toimittaneet Dan Ben-Amos ja Kenneth S. Goldstein, 11-74, Hague: Mouton \& Co. N. V.

Hytönen, Elina. 2006. "Muuttuneen tajunnantilan pohdintaa: Transsi ja jazzmuusikkojen huippukokemukset." Elore 13(2). https://doi.org/10.30666/elore.78592

Johnstone, Tom ja Klaus R. Scherer. 2004. "Vocal Communication of Emotion." Teoksessa Handbook of Emotions. Second Edition, toimittaneet Michael Lewis ja Jeannette M. Haviland-Jones, 220-235. New York, NY: Guilford Press.

Karjalan kielen sanakirjan. 2009. Helsinki: Kotimaisten kielten tutkimuskeskuksen verkkojulkaisuja 18. http://kaino.kotus.fi/cgi-bin/kks/kks etusivu.cgi. Päivitettävä julkaisu. Päivitetty 24.2.2020 [viitattu 2.6.2020].

Kemal, Salim ja Ivan Gaskell. 1999. Performance and authenticity in the arts. Cambridge, UK: Cambridge University Press. https://doi.org/10.1017/CBO9780511520051.001

Kielitoimiston sanakirja. 2020. Helsinki: Kotimaisten kielten keskuksen verkkojulkaisuja 35. URN:NBN:fi:kotus-201433. https://www.kielitoimistonsanakirja.fi. Päivitettävä julkaisu. Päivitetty 24.2.2020 [viitattu 2.6.2020].

Kivikangas, Matias. 2015. Emotion and social context in a digital game experience. Helsinki: Helsingin yliopiston. http://urn.fi/URN:ISBN:978-951-51-1818-9

Konkka, Unelma. 1985. Ikuinen ikävä: Karjalaiset riitti-itkut. Helsinki: Suomalaisen Kirjallisuuden Seura. 
Levenson, Robert W. 2003."Blood, Sweat, and Fears. The Autonomic Architecture of Emotion." Annals of the New York Academy of Sciences 1000(1): 348-366. https://doi.org/10.1196/ annals.1280.016

Lönnrot, Elias. 1836: "Itkuwirsistä Wenäjän Karjalasta." Mehiläinen syyskuu 1836.

Margulis, Elizabeth Hellmuth. 2014. On Repeat: How Music Plays the Mind. New York: Oxford University Press. https://doi.org/10.1093/acprof:oso/9780199990825.001.0001

Massumi, Brian. 1995. "The Autonomy of Affect." Cultural Critique 31, The Politics of Systems and Environments, Part II: 83-109. https://doi.org/10.2307/1354446

Mendes, Wendy Berry. 2016. "Emotion and the Autonomic Nervous System." Teoksessa Handbook of Emotions. 4th edition, toimittaneet Lisa Feldman Barrett, Michael Lewis ja Jeannette M. Haviland-Jones, 166-181. New York, NY: Guilford Press.

Nenola-Kallio, Aili. 1982. Studies in Ingrian Laments. Helsinki: Suomalainen tiedeakatemia.

Newell, Sasha. 2018. "The Affectiveness of Symbols Materiality, Magicality, and the Limits of the Antisemiotic Turn."Current Anthropology 59(1).1-22.https://doi.org/10.1086/696071

Niemi, Jarkko. 2002. "Inkeriläisten itkuvirsien musiikilliset rakenteet." Teoksessa Inkerin itkuvirret. Ingrian Laments, toimittanut Aili Nenola, 694-707. Helsinki: Suomalaisen Kirjallisuuden Seura.

Noë, Alva. 2009. Out of Our Heads: Why You Are Not Your Brain, and Other Lessons from the Biology of Consciousness. New York: Hill and Wang.

Pink, Sarah. 2015. Doing Sensory Ethnography. 2nd edition. Los Angeles: SAGE.

Porkka, Volmari. 1883. “Inkerin itkuvirsistä." Valvoja 3(7). 199-208.

Povrzanović Frykman, Maja. 2016. "Sensitive Objects of Humanitarian Aid. Corporeal Memories and Affective Continuities." Teoksessa Sensitive Objects: Affect and Material Culture, toimittaneet Jonas Frykman ja Maja Povrzanović Frykman, 79-104. Lund: Nordic Academic Press. https://doi.org/10.21525/kriterium.6

Rüütel, Ingrid ja M. Remmel. 1980. "Opït notatsii i issledovaniya vepskikh prichitaniy." Teoksessa Finno-ugorskiy muzïkal'n'iy fol'klore i vzaimosvyazi s sosednimi kul'turami, toimittanut Ingritd Rüütel, 169-193. Tallinna: Eesti Raamat.

Saastamoinen, Ilpo. 1999b. "Aunuksen itkut musiikkina - katsaus Pertti Virtarannan kokoelmiin." Musiikin suunta 21(3): 35-44.

Salmela, Mikko. 2017. "Affektiivinen käänne. Yksi vai monia? Käsitteellisiä ja metodologisia pohdintoja." Tieteessä tapahtuu 35(2). 32-35. https://journal.fi/tt/article/ view/61405/23049

Salmenhaara, Anja. 1976[1967]. "Itkuvirsien musiikillisesta hahmotuksesta." Teoksessa Paimensoittimista kisällilauluun: Tutkielmia kansanmusiikista 1, toimittaneet Heikki Laitinen ja Simo Westerholm, 124-156. Alajärvi: Kansanmusiikki-instituutti.

Scheer, Monique. 2012."Are Emotions a Kind of Practice (And Is That What Makes Them Have a History)?: A Bourdieuian Approach to Understanding Emotion." History and Theory 51(2): 193-220. https://doi.org/10.1111/j.1468-2303.2012.00621.x

Siikala, Anna-Leena. 1978. The Rite Technique of the Siberian Shaman. Helsinki: Suomalainen tiedeakatemia.

Siikala, Anna-Leena. 1984. Tarina ja tulkinta. Tutkimus kansankertojista. Helsinki: Suomalaisen Kirjallisuuden Seura. 
Silvonen, Viliina. tulossa. "Formulaic Expression in Olonets Karelian Laments: Textual and Musical Structures of the Composition of Non-Metric Oral Poetry."Teoksessa Weathered Words: Formulaic Language and Verbal Art, toimittaneet Frog ja William Lamb.

Silvonen, Viliina ja Eila Stepanova. 2020. "Language, Music and Emotion in Lament Poetry: The Embodiment and Performativity of Emotions in Karelian Laments." Teoksessa The Routledge Handbook of Language and Emotion, toimittaneet Sonya Pritzker, Janina Fenigsen ja James M. Wilce, 203-222. Lontoo: Routledge. https://doi. org/10.4324/9780367855093-12

Slaby, Jan. 2018. "Affective Arrangements and Disclosive Postures. Towards a PostPhenomenology of Situated Affectivity." Phänomenologische Forschungen 2018(2). 197-216. https://doi.org/10.28937/1000108209

Slaby, Jan. 2019. "Affective Arrangements." Teoksesa Affective Societies: Key Concepts, toimittaneet Jan Slaby ja Christian von Scheve, 109-118. Lontoo: Routledge. https:// doi.org/10.4324/9781351039260-9

Stepanova, Aleksandra. 2012. Karjalaisen itkuvirsikielen sanakirja. Helsinki: Suomalaisen Kirjallisuuden Seura.

Stepanova, Eila. 2014. Seesjärveläisten itkijöiden rekisterit: Tutkimus äänellä itkemisen käytänteistä, teemoista ja käsitteistä. Helsinki: Suomen Kansantietouden Tutkijain Seura.

Tarvainen, Anne. 2012. Laulajan ääni ja ilmaisu: Kehollinen lähestymistapa laulajan kuuntelemiseen, esimerkkinä Björk. Tampere: Tampere University Press.

Tenhunen, Anna-Liisa. 2006. Itkuvirren kolme elämää. Helsinki: Suomalaisen Kirjallisuuden Seura.

Tolbert, Elizabeth. 1988. The Musical Means of Sorrow: The Karelian Lament Tradition. Los Angeles: University of California.

Tolbert, Elizabeth. 1990. "Women Cry With Words: Symbolization of Affect in the Karelian Lament." Yearbook for Traditional Music 22: 80-105. https://doi.org/10.2307/767933

Urban, Greg. 1988. "Ritual Wailing in Amerindian Brazil." American Anthropologist 90: 382400. https://doi.org/10.1525/aa.1988.90.2.02a00090

Visakko, Tomi. 2015. Self-promotion as semiotic behavior: The mediation of personhood in light of Finnish online dating advertisements. Helsinki: Helsingin yliopisto. http://urn.fi/ URN:ISBN:978-951-51-1399-3

Väisänen, Armas Otto. 1990 [1940-1941]. "Itkuvirsi karjalaisten kohtalosta." Teoksessa Hiljainen haltioituminen. A. O. Väisäsen tutkielmia kansanmusiikista, toimittanut Erkki Pekkilä, 132-137. [Julkaistu ensikerran Kalevalaseuran vuosikirja 20-21.] Helsinki: Suomalaisen Kirjallisuuden Seura.

Wetherell, Margaret. 2012. Affect and Emotion: A New Social Science Understanding. Los Angeles ja Lontoo: SAGE. https://doi.org/10.4135/9781446250945

Wilce, James M. 2009a. Crying Shame. Metaculture, Modernit, and the Exaggerated Death of Lament. Malden, Ma: Blackwell Publishers.

Wilce, James M. 2009b. Language and Emotion. Cambridge: Cambridge University Press.

Wilce, James M. 2011. "Sacred Psychotherapy in the 'Age of Authenticity': Healing and Cultural Revivalism in Contemporary Finland." Religions 2011(2): 566-589. https://doi. org/10.3390/rel2040566 


\section{Liite 1. \\ Haastattelumuistio. Tutkimus arkistojen itkuvirsien affektiivisuudesta. Haastattelija: Viliina Silvonen}

\section{Itkuvirsien kuunteluhaastattelun kuvaus}

Vertailuryhmän haastattelussa haastateltavat kuuntelivat ensin itkuvirsiäänitteen ja kertoivat vapaasti, mitä kuunteleminen heissä herätti, miltä tuntui kuunnella, heräsikö joitakin ajatuksia. Ennen kuuntelua haastattelija kertoi, että tutkimuksessa tarkastellaan itkuvirsien tunteita, mutta että kuunnellessa ei tarvitse erityisesti kiinnittää huomiota mihinkään, vaan kuunnella avoimena. Haastattelija vältti kaikenlaisia johdattelevia kysymyksiä ja kommentteja ennen kuin kuuntelija oli vapaasti kertonut ja kommentoinut kuulemaansa. Vasta haastattelun lopuksi haastattelija kertoi, mistä kuunnellussa itkuvirressä oli kyse, mitä teksti käsitteli ja minkälaisia tulkintoja hän on tutkimuksessaan itse tehnyt kyseisestä itkuvirrestä.

Haastattelu- ja kuuntelutilanne järjestettiin kotioloissa vapaamuotoisesti, yksi puutarhassa kesän 2020 koronatilanteen vuoksi. Kaksi haastatteluista oli parihaastatteluita, joissa molemmat haastateltavat tunsivat toisensa erittäin hyvin ja tilanne oli heille sen puolesta luonnollinen. Parihaastattelu teki haastateltavalle mahdolliseksi keskustella tai kommentoida kokemusta toisen itkuvirsiä tuntemattoman kanssa, minkä myötä haastattelija pystyi vähentämään omaa osuuttaan. Näissäkin haastatteluissa kommentointi oli varsin vapaasti yksilönä vastaamista.

Koska oletuksena oli, että kuuntelu ei välttämättä herätä varsinaisesti tunteita, oli keskustelun avaava kysymys: "Minkälaisia ajatuksia tai fiiliksiä kuunnellessa heräsi?"Yksi haastateltava alkoi kertoa ja kommentoida kuulemaansa oma-aloitteisesti äänitteen päätyttyä ennen kysymystä. Muita vapaan kertomisen ja keskustelun tukena käsiteltyjä aiheita olivat:

- miltä äänitteeltä kuultu kuulostaa

- ymmärtääkö haastateltava tekstistä tai kielestä mitään

- itkuvirren eteneminen, mahdolliset muutokset

- erot eri itkuvirsissä (kuuntelijat D ja E)

Kevään ja kesän 2020 koronavirustilanne vaikeutti haastattelujen järjestelyitä, joten pidin haastateltavien määrän pienenä.

\section{Kuunneltavat itkuvirret}

SKNA 7592:3/JFS2.

Fon.985/4. 


\section{Haastateltavat}

Kaikki haastateltavat (kuuntelijat) ovat nuoria aikuisia, jotka asuvat pääkaupunkiseudulla. Neljä on äidinkieleltään suomenkielisiä, yksi kaksikielinen, äidinkieli ruotsi.

Haastattelu 16.6.2020, kuuntelija-A.

kotoisin pääkaupunkiseudulta, vähän yleistä taustatietoa itkuvirsistä

Haastattelu 6.7.2020, kuuntelija-B.

kotoisin Itä-Suomesta, ei ennakkotietoja itkuvirsistä

Haastattelu 6.7.2020, kuuntelija-C.

kotoisin Itä-Suomesta, ei ennakkotietoja itkuvirsistä

Haastattelu 13.8.2020, kuuntelija-D.

kotoisin pääkaupunkiseudulta, vähän yleistä taustatietoa itkuvirsistä

Haastattelu 13.8.2020, kuuntelija-E.

kotoisin pääkaupunkiseudulta, ruotsinkielinen/kaksikielinen, ei ennakkotietoja itkuvirsistä

\section{Haastattelujen sisältöjen kuvaukset}

Kuuntelija A

SKNA7592:3: Kuuntelija kuvaili, että äänitteen esitys kuulosti itkuiselta, siinä oli surua, ja alakulo tarttui. Hän huomasi asteittaista tunteen tai surun nousua ja kuvaili itkuvirren alkaneen neutraalisti, että esittäjä "hymähteli", mutta tästä ei voinut tietää oliko se huvittunutta vai "oikeasti" surua, kuitenkin esityksen lopussa esittäjä ei enää tunteeltaan pystynyt jatkamaan vaan jätti kesken.

Fon.985/4: Itkuvirsi jäi kuuntelijalle epämääräiseksi ja vaikeaksi tulkita tai suhtautua.

Kuuntelija B

SKNA7592:3: Kuuntelija kertoo ajatuksiaan siitä, mitä itkuvirressä kerrotaan: aluksi vaikuttaa, että esittäjä kertoo jonkun muun kokemuksista, mutta lopuksi vaikuttaakin, että esittäjälle itselleen olisikin tapahtunut jotakin. Aluksi esitys kuulosti toteavalta, kunnes yhtäkkiä tapahtui muutos syvempään ja esittäjä alkoikin kuvailla yksityiskohtia. Kuunteleminen tuntui kuuntelijasta kotoisalta, koska ääni toi mieleen hänen isoäitinsä; mielikuvatasolla hän kertoo ajatelleen itkijän vanhana naisena kyyryssä. Esityksen etenemisestä ja intensiteetistä kuuntelija toteaa alun olleen tasapaksua, mutta "kaava" rikkoutui jossain kohti, intensiteetti kasvoi ja loppu meni nopeasti. 


\section{Kuuntelija C}

SKNA7592:3: Kuuntelija toteaa, ettei alku vastannut hänen mielikuvaansa itkuvirrestä, kun esittäjä ei itkenyt, mutta sitten tapahtui muutos, jonka hän hahmotti sävelmää kuunnellen ja äänessä. Kuuntelija ei ymmärtänyt sanoista mitään, vaan "empatiseerasi ääntä".

Kuuntelija D

SKNA7592:3: Kuuntelija kuvaili, että aluksi itkuvirsi kuulosti kuin esittäjä olisi hyvästelemässä. Se ei vielä kuulostanut lohduttomalta, mutta esityksen edetessä kuuntelijan olisi tehnyt mieli lohduttaa itkijää. Tätä ajatustaan tai tulkintaansa kuuntelija perusteli sillä, että ääni alkoi sortua ja väristä ja esittäjän nyyhkyttäminen tai niiskuttaminen kuului. Esityksen etenemistä ja muutoksia kokonaisuudessa kuuntelija hahmotti tunnetta virittävänä alkuna ja tunteen kasvamisena jotenkin esityksessä tehtynä: että esittämisessä on jokin kaava, joka saa aikaan itkun reaktioita. "Uskon että se tunne on aito, mutta se on tullut tietystä kaavasta."

Fon.985/4: Kuuntelijoiden D ja E oli vaikea suhtautua esitykseen, koska he tiesivät kuuntelevansa itkuvirttä mutta kuulivat naurua.

Eri itkuvirsiä vertaillessa kuuntelija kuvaili jälkimäistä hersyväksi ja ensimmäistä monotoniseksi.

\section{Kuuntelija E}

SKNA7592:3: Kuuntelija kertoi ensin, ettei tunnistanut ollenkaan kieltä, ettei siinä ollut mitään tuttua, ja kuvaili kuullun herättäneen vaihtelevia mielikuvia eri kulttuureista. Kaikkiaan hän kertoi huvittuneensa siitä mielikuvasta, että ylipäätään tällainen perinne on, mutta ei osannut sanoa, mistä se johtui. Esityksen tunteita hän piti "ei-aitona, näyteltyinä". Kuuntelija mainitsi, että rytmin toisteisuus ja vieras kieli tuntuivat rauhoittavalta etenkin kuuntelun alussa.

Fon.985/4: Kuuntelijoiden D ja E oli vaikea suhtautua esitykseen, koska he tiesivät kuuntelevansa itkuvirttä mutta kuulivat naurua.

Eri itkuvirsien kuultua kommentoidessa kuuntelija kuvailee jälkimmäisen esittäjän ääntä ikään kuin kovemmaksi ja rennommaksi, touhukkaammaksi kuin ensimmäistä.

Haastattelijan kommentti

Se, että kuuntelijat B ja D puhuvat "kaavasta" tunteen ilmenemisen yhteydessä, on sattumaa. Haastattelija ei missään vaiheessa puhunut kaavasta, eivätkä nämä haastateltavat ole keskustelleet toistensa kanssa tai ole toisilleen tuttuja.

FM Viliina Silvonen (orcid.org/0000-0002-7191-4956) on itkuvirsiperinteeseen erikoistunut folkloristiikan väitöskirjatutkija Helsingin yliopistossa. 